\title{
Trust in Virtual Teams: A Multidisciplinary Review and Integration
}

Janine Hacker

University of Zurich

jhacker@ifi.uzh.ch

\section{Michael Johnson}

Louisiana State University

\section{Carol Saunders}

University of South Florida

\section{Amanda L. Thayer}

The University of Akron

\section{Abstract}

Organizations have increasingly turned to the use of virtual teams (VTs) to tackle the complex nature of today's organizational issues. To address these practical needs, VTs researchers from different disciplines have begun to amass a large literature. However, the changing workplace that is becoming so reliant on VTs comes with its own set of management challenges, which are not sufficiently addressed by current research on VTs. Paradoxically, despite the challenges associated with technology in terms of its disruption to trust development in VTs, trust is one of the most promising solutions for overcoming myriad problems. Though the extant literature includes an abundance of studies on trust in VTs, a comprehensive multidisciplinary review and synthesis is lacking. Addressing this gap, we present a systematic theoretical review of 124 articles from the disparate, multidisciplinary literature on trust in VTs. We use the review to develop an integrated model of trust in VTs. Based on our review, we provide theoretical insights into the relationship between virtuality and team trust, and highlight several critical suggestions for moving this literature forward to meet the needs of workplaces of the future, namely: better insight into how trust evolves alongside the team's evolution, clarity about how to adequately conceptualize and operationalize virtuality, and greater understanding about how trust might develop differently across diverse types of virtual contexts with various technology usages. We conclude with guidelines for managing VTs in the future workplace, which is increasingly driven and affected by changing technologies, and highlight important trends to consider.

Keywords: Virtual teams, Trust, Swift trust, Virtuality, Team processes

\section{Introduction}

In an attempt to create business value (Chatfield, Shlemoon, Redublado, \& Darbyshire, 2014), as well as capture diverse knowledge resources, time cost savings, and more affordable opportunities for collaboration, organizations are increasing their reliance on virtual teams (VTs) (Gibson \& Gibbs, 2006). A 2003 Gartner study estimated that $60 \%$ of all major corporations used VTs (see Gibson \& Gibbs, 2006; Martins, Gilson, \& Maynard, 2004). In 2012, the estimate for 2016 grew to $80 \%$ (Gartner, 2012). As rosy as this estimate appears to have been, it was exceeded. A survey of VTs in 2016 found that $85 \%$ of the respondents in corporations work on VTs. Another survey of 3000 managers located in 100 countries reported 
that $40 \%$ of the employees in their organizations spend at least half their time on work involving VTs (Hoch \& Dulebohn, 2017). Furthermore, many of these VTs (48\%) are global, as compared to $41 \%$ in 2014 and 33\% in 2012 (RW ${ }^{3}$ CultureWizard, 2016). Due to their increasing prevalence and reliance on information technologies, VTs have been studied steadily and frequently by researchers in information systems (IS), human resource management (HRM), management, computer science, psychology, and other disciplines for two decades. Indeed, VTs continue to be an important topic in IS research (e.g., Bartelt \& Dennis, 2014; Chatfield et al., 2014; Dennis, Robert, Curtis, Kowalczyk, \& Hasty, 2012).

However, the changing workplace that is becoming so reliant on VTs comes with its own set of management challenges (Chatfield et al., 2014; Jimenez, Boehe, Taras, \& Caprar, 2017; Lukić \& Vračar, 2018), which are not sufficiently addressed by current research on VTs and have remained unsolved up until now. Pearlson, Saunders, \& Galletta (2016) suggest three types of challenges that managers of VTs must overcome: (1) Communication (e.g., scheduling meetings, passing work across time zones, inability to see communication dynamics such as facial expressions and gestures); (2) Technology (e.g., ensuring workers have proficiency across a range of technologies, aligning technology across members); and (3) Team diversity (e.g., building trust, norms and shared meanings; establishing a group identity). Though trust development is suggested as one challenge (amongst others), we consider it as an important prerequisite for VT leaders to solve communication- and technology-related challenges. In fact, the accumulating research across a range of disciplines, among them IS, management, psychology, computer science and communication, shows that interpersonal trust can help overcome many VT challenges, and some have identified it as the heart of VT functioning (e.g., Jarvenpaa, Knoll, \& Leidner, 1998). Trust improves collaboration and knowledge sharing (AlAni, Marczak, Prikladnicki, \& Redmiles, 2013; Henttonen \& Blomqvist, 2005; Jimenez et al., 2017), coordination, performance (Joshi, Lazarova, \& Liao, 2009; Lukić \& Vračar, 2018), and is overall a critical success factor for VTs (Verburg, Bosch-Sijtsema, \& Vartiainen, 2013). Hence, VT leaders need to continuously make efforts to create, reinforce, and maintain trust between the members of their teams as well as between themselves and their team members (e.g., AlAni, Marczak, et al., 2013; Hambley, O’Neill, \& Kline, 2007; Henttonen \& Blomqvist, 2005; Hertel, Geister, \& Konradt, 2005; Joshi et al., 2009; Liao, 2017; Lukić \& Vračar, 2018; Staples, 1997; Thomas \& Bostrom, 2008; Zander, Zettinig, \& Mäkelä, 2013). However, even though trust has become one of the most studied variables in the VTs literature (Gilson, Maynard, Jones Young, Vartiainen, \& Hakonen, 2015), researchers and practitioners are limited by a startling lack of clarity about what trust is in this context, due to the myriad ways it has been conceptualized and studied in VTs research.

Taken together, research suggests that VTs will be a fixture in the workplace of the future and that trust may serve as an important mechanism for overcoming challenges associated with technology use, communications, and team diversity. Thus, a better understanding of how to facilitate VT functioning through trust will be critical for both HRM professionals and IS managers in guiding the workforce of the future in a more efficient and effective way. Against this backdrop, the major aims of this paper are two-fold. The primary goal is to identify the current state of research on trust in VTs, develop a conceptual model that integrates research findings and serves as an initial guide to HRM practitioners and VT managers, and provide a roadmap for future research in this domain. The secondary goal of this paper is to encourage conversations across disciplines to provide fresh insights into the role of trust in VTs and how HRM practitioners and IS managers can best facilitate its development. 
To this end, we conduct a systematic theoretical review (Ortiz de Guinea \& Paré, 2017; Paré, Trudel, Jaana, \& Kitsiou, 2015) of 124 articles from the disparate, multidisciplinary literature on trust in VTs. Given the current state of the literature, this review is both timely and needed. Previous reviews have separately considered VTs (e.g., Chatfield et al., 2014; Gibbs, Sivunen, \& Boyraz, 2017; Gilson et al., 2015; Hertel et al., 2005; Martins et al., 2004; Powell, Piccoli, \& Ives, 2004), team virtuality (e.g., Kirkman \& Mathieu, 2005), interpersonal trust (e.g., Lewicki, Tomlinson, \& Gillespie, 2006), and definitions of trust (McKnight \& Chervany, 2000). Even though seminal articles on trust in VTs (i.e., Jarvenpaa et al., 1998; Jarvenpaa \& Leidner, 1998) have been cited over 6,000 times and these citations have been growing exponentially over the last decade, we know of no other broad-based, multidisciplinary review that looks at the phenomenon of trust in VTs. This suggests research and practice would benefit from a synthesis and recommendations to guide future scholarly work as well as HR management decision-making.

In this paper, we review and integrate the IS, computer science, communications, management, and psychology literatures on trust in VTs. In particular, the comprehensive multidisciplinary review was used to develop an integrative conceptual model of the current nomological network on trust in VTs. It identifies knowledge gaps and ways to incorporate different conceptualizations emerging from the review. To move the science and practice of VTs forward, we offer new directions for scholarly research, insights into potential synergies across disciplines, and practical guidance for managing a workforce of the future whose members increasingly work in VTs and face various technology challenges.

\section{Key Definitions}

To provide a foundation for our integrative, multidisciplinary review and our discussion of theoretical and practical recommendations, we first begin by defining key concepts, including: trust, teams and VTs, and virtuality.

\subsection{Trust}

Interpersonal trust has been conceptualized in a variety of ways across the literature (McKnight, Cummings, \& Chervany, 1998). It is generally considered the expectations of another's conduct and/or an acceptance of vulnerability (e.g., McAllister, 1995; Rousseau, Sitkin, Burt, \& Camerer, 1998). According to our review, the most common definition of trust utilized is Mayer and colleagues' (1995) "the willingness of a party to be vulnerable to the actions of another party based on the expectation that the other will perform a particular action important to the trustor, irrespective of the ability to monitor or control that other party" (pg. 712). More recent studies use the definition proposed by Lewicki, McAllister \& Bies (1998, pg. 439): "Confident, positive expectations about the conduct of another", which shares similarities to Mayer and colleagues' view. The clustering around a set of definitions is encouraging; however, scholars have been embracing this broad definition when more specific conceptualizations may be more theoretically appropriate (see Section 4.1).

\subsection{Teams and Virtual Teams}

A team is defined as a group of "individuals interacting adaptively, interdependently, and dynamically towards a common and valued goal" (Salas, Burke, \& Cannon-Bowers, 2000, pg. 341). Teams vary across a range of dimensions (e.g., task interdependence, role structure, lifespan) (Wildman et al., 2012). As a particular type of team, VTs are frequently defined as "groups of 
geographically and/organizationally dispersed co-workers that are assembled using a combination of telecommunications and information technologies to accomplish an organizational task" (Townsend, DeMarie, \& Hendrickson, 1998, pg. 18). The VT literature has roots in the IS discipline's systematic studies of VT precursors called Group Decision Support Systems (GDSS) or Group Support Systems (GSS). A GDSS (GSS) is an interactive system that combines communication, computer, and decision technologies to support communication, coordination processes and information processing when formulating and solving unstructured problems in group meetings (Maier, 2007, pg. 277). Concomitant streams of research on GDSS and GSS were conducted by faculty and students at University of Minnesota and the University of Arizona, respectively, as far back as the 1980s and 1990s. As a specific example, Jay Nunamaker and colleagues/students summarized twelve years of GSS lab and field studies conducted at the University of Arizona during that time period (Nunamaker, Briggs, Mittleman, Vogel, \& Pierre, 1996).

Early VTs were categorized using a single, identifiable phenomenon (i.e., whether or not they used an information and communication technology (ICT) or whether or not the teams were geographically separated), but more recent VT studies have incorporated a more nuanced, multi-dimensional view of what it takes to make a team more or less virtual. For example, the commonly-cited definition by Townsend and colleagues (1998) focuses on the geographic and organizational aspects of VTs, two of the three most common boundaries mentioned in definitions of VTs (Martins et al., 2004). We use a more encompassing definition of VTs: "teams whose members use technology to varying degrees in working across locational, temporal, and relational boundaries to accomplish an interdependent task" (Martins et al., 2004, pg. 808). Thus, technology is at the heart of our definition of VTs.

\subsection{Virtuality}

Virtuality is the concept that determines whether a team is more or less virtual (Gibson \& Gibbs, 2006). We define virtuality as a multi-faceted higher-order construct encompassing a team's independent identifying dimensions that signify degrees of dispersion or discontinuity. Different researchers hold separate views as to what dispersions and discontinuities constitute the identifying dimensions. For example, discontinuities can be barriers to VTs such as geographic separation, cultural differences, time zone differences, and organizational membership which contribute to many problems in VT functioning (Chudoba, Wynn, Lu, \& Watson-Manheim, 2005; Lu, Watson-Manheim, Chudoba, \& Wynn, 2006). Some more common views of types of dispersions are: geographic dispersion, temporal dispersion, and structural dispersion (O'Leary \& Cummings, 2007); geographic dispersion, electronic dependence, dynamic structural arrangements, and national diversity (Gibson \& Gibbs, 2006); location, distance and time (Jimenez et al., 2017); and the degree of face-to-face contact (Fiol \& O'Connor, 2005). Even though most views of virtuality include a geographic dimension, Kirkman \& Mathieu (2005, pg. 702) dispute using it as an identifier and instead focus solely on three technology dimensions: "(a) the extent to which team members use virtual tools to coordinate and execute team processes...(b) the amount of informational value provided by such tools, and (c) the synchronicity of team member virtual interaction." While there is considerable debate about the specific identifying dimensions, there is also considerable overlap among them. Furthermore, most VT researchers now agree that dimensions are combined in some way to create a composite construct that indicates the degree of virtuality in the team and reflects how technology helps or impedes its performance. 


\section{Approach of the Literature Review}

To assess the literature on trust in VTs, we adopted a systematic theoretical review approach (Ortiz de Guinea \& Paré, 2017; Paré et al., 2015). Systematic theoretical reviews "synthesize the literature often bringing different streams of research together but they go a step further in developing a theoretical framework or model" (Ortiz de Guinea \& Paré, 2017, pg. 75). Our search strategy is called an "exhaustive coverage with selective citation" (Ortiz de Guinea \& Paré, 2017, pg. 79) meaning that we attempted to look at a relatively complete census of relevant published conceptual and empirical articles considering both trust and VT, but only discussed a selected sample of works (Ortiz de Guinea \& Paré, 2017; Paré et al., 2015). We recognized that it was impractical to capture all articles at the intersection of two large literatures, so the theoretical review approach seemed appropriate in this regard. Our search was systematic in that we adopted a structured approach to searching, analysing, evaluating, and synthesizing research (e.g., Kitchenham, 2004). Guided by a specific research question, systematic reviews involve a documented and reproducible review process and lead to a comprehensive overview of relevant literature (e.g., Okoli \& Schabram, 2010). In particular, we developed a strategy for defining the sources of the search (i.e., databases instead of journals), selecting search terms for our keyword searches, combining them with search operators, using the appropriate search fields, and coding the articles we ultimately selected (vom Brocke et al., 2015). In the following, details regarding the literature search and coding are provided.

\subsection{Literature Search}

To review the "state of the science" and gather a broad range of articles discussing trust in VTs, an extensive, systematic search of about the last decade of research (2003-2015) was conducted within databases representing disciplines where these articles were likely to be found: Proquest/ABI Inform, EBSCOHost, Google Scholar, ACM Digital Library, and IEEE Xplore databases. We decided that a search of databases would be broader than one based on specific journals (vom Brocke et al., 2015), especially considering the possibility that we might have missed selecting journals from some of the multiple disciplines whose researchers are exploring the VT phenomenon. Additionally, we conducted a backwards search (vom Brocke et al., 2015; Webster \& Watson, 2002) on key trust in VTs articles using Google Scholar (e.g., Jarvenpaa et al., 1998; Jarvenpaa \& Leidner, 1998). We queried for the terms ("virtual team" OR "distributed team") AND ("trust" OR "swift trust"). "Swift trust" was selected as a keyword because it is a type of trust that seems to be particularly associated with VTs. In all, this search returned more than 17,000 potential articles.

Abstracts, titles, and keywords are among the most frequently used search fields (vom Brocke et al., 2015). Hence, we used these three search fields to look for references to trust in VTs, resulting in an initial set of 750 relevant articles. Subsequently, articles were excluded if they were less than five pages, were an extended abstract or foreword, in a language other than English, or did not meaningfully speak to trust in VTs. We considered it to be a meaningful treatment if trust was in the article's model or theoretical framework, hypotheses, or propositions, or if it was discussed in major article sections (i.e., not just a paragraph). This resulted in a set of 188 articles. After a more extensive reading of each article, a subset of these articles was determined to not meaningfully speak to trust in VT. During this step, at least two members of the author team assessed the articles for relevance to the literature review goals (vom Brocke et al., 2015). We did not assess them for quality since some argue that "appraisals of quality may not be necessary" (Paré et al., 2015, pg. 189), especially since "quality criteria from 
other disciplines... are often not applicable to IS research" (vom Brocke et al., 2015, pg. 211). The selection process resulted in a final set of 124 articles (see Appendix A for a summary).

\subsection{Coding}

For each of the 124 articles in the review sample, we coded study characteristics (study design, study setting, participant type), trust conceptualizations (swift trust, general trust, time-based trust, multi-faceted trust, dispositional trust, institutional trust), use of VT technology (i.e., face-to-face only, videoconferencing/phone, email/chat, mixed), dimensions of virtuality (geographic distance, organization, time zone, team dispersion, national culture), technology capabilities, processes, antecedents, moderators, and consequences of trust. We also extracted the journal's discipline (management, psychology, information systems, computer science, and communication). To ensure a high-quality coding procedure, at least two members of the author team coded each article and differences were discussed to achieve agreement as recommended by Saldaña (2015).

\section{Literature Review and Synthesis}

Most studies in the trust in VTs literature adopt a variance approach, meaning they predominantly focus on studying relationships among independent and dependent variables (Burton-Jones, McLean, \& Monod, 2015). Accordingly, following past reviews (e.g., Narayanan, Zane, \& Kemmerer, 2011) and based on the findings of our review, we present an integrative model (Figure 1) that incorporates three broad categories of factors: antecedents, consequences, and moderators.

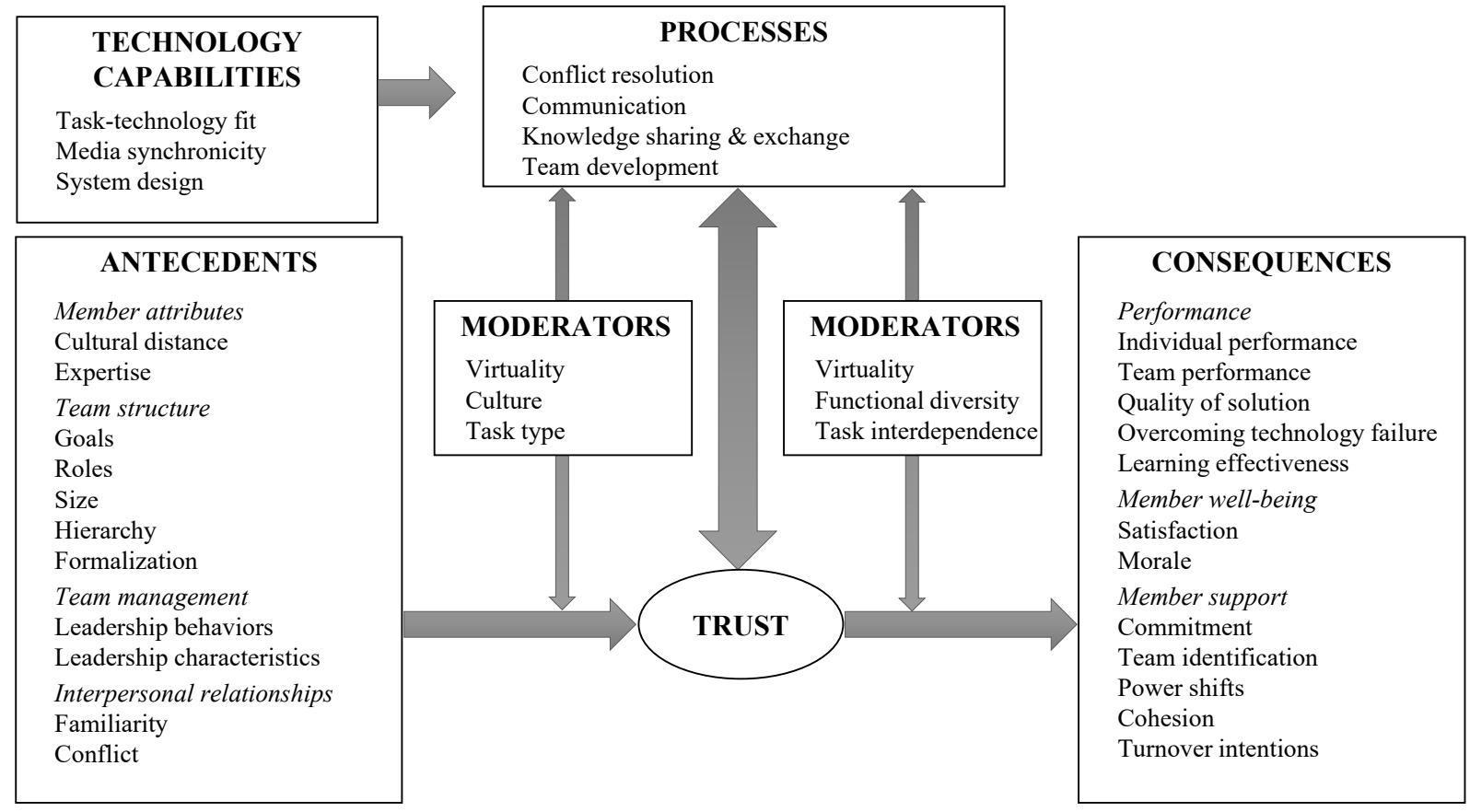

Figure 1. Integrated Conceptual Model of the Nomological Network of Trust in VTs

We additionally consider the reciprocal relationships among these factors, as well as technological capabilities and processes. In the following, we first present overall trends from the literature. Then, we summarize findings about components of our integrative model. 


\subsection{General Research Trends}

Our broad review of the literature on trust in VTs suggests that researchers in IS as well as in other disciplines often focus on different perspectives of trust. For example, the VT literature often views trust as a static or unidimensional concept; however, we argue that trust should be studied as a dynamic, evolving construct that changes form as VTs progress. Further, we propose that different forms of trust support, and are supported by, such VT processes as communication and knowledge sharing. We also show that the literature as a whole fails to employ a consistent view of virtuality in VT functioning. The level of a team's virtuality (or what it takes to make teams virtual) is dependent on technology and affects the trust development and VT development process. In addition, the study of trust and virtuality in the VT literature remains somewhat fragmented across a number of disciplines. Unfortunately, researchers from many disciplines are looking at different isolated aspects of trust and virtuality, making it difficult to compare the findings across disciplines. It is time for researchers to create a more integrated picture of the complex components of this picture. Indeed, because conceptual reviews that bridge disciplinary backgrounds have the strongest potential for contribution (Short, 2009), our multidisciplinary approach presents a more integrated understanding of the complex components of trust in VT. By more fully conceptualizing trust and consistently defining and operationalizing virtuality, it may be possible to compare findings across disciplines and more fully understand trust in VT in a variety of contexts. We now discuss these trends in more detail.

\subsubsection{Multidisciplinary Investigation and Conceptualizations of Trust}

The study of trust in VTs is inherently multidisciplinary (see Table 1). Though the IS discipline has most studied this phenomenon (48 studies), interest in computer science and communication disciplines has been growing, and management journals steadily published a large number of the papers identified (46 in total).

Different disciplines conceptualize the trust construct in diverse ways. Although the difference between these types of trust may seem nuanced and specific, the trust literature generally considers each as a different concept (e.g., Lewicki \& Bunker, 1995; Mayer et al., 1995; McKnight et al., 1998). That is, something like swift trust is a separate construct than multifaceted trust despite the fact that they share the trust name, and, thus, the distinctions are important. Through our review, we uncovered six main conceptualizations of trust. These conceptualizations are different ways of looking at and understanding trust and include swift trust (i.e., trust that is built quickly based on surface-level cues rather than interaction or knowledge of the trustee), as well as generalized trust (i.e., a single, unidimensional construct reflecting willingness to accept vulnerability to risk), time-based trust (i.e., static trust vs. trust that is dynamic and evolves), multi-faceted trust (i.e., trust as a multidimensional construct, such that individuals can be trusted in particular ways and for particular behaviours), dispositional trust (i.e., trust as a function of a pre-existing characteristic of the trustor), and institution-based trust (i.e., trust that is based on norms and rules created by institutions that guide individual behaviour). For more information on the definitions of these constructs and example citations, see Appendix B.

From a conceptual standpoint, there are interesting trends in terms of how each discipline has treated the trust construct, as indicated in Table 1. The time-based conceptualizations of trust tend to explore the dynamic and temporal characteristics of the VT environment. Such dynamic conceptualizations are few in number and are more frequently found in the 
management and computer science literatures. Additionally, although the term was first coined by management researchers (Meyerson, Weick, \& Kramer, 1996) and subsequently explored by several psychology and management researchers (e.g., Bosch-Sijtsema, 2007), most swift trust studies are from IS and computer science disciplines. This review is one opportunity to disseminate findings to other disciplines. It is also important to note that all disciplines have underexplored dispositional and institution-based trust in VTs. More work needs to be done on these forms of trust.

\begin{tabular}{|c|c|c|c|c|c|c|c|c|c|c|c|c|c|}
\hline & \multicolumn{2}{|c|}{$\begin{array}{c}\text { Generalized } \\
\text { trust }\end{array}$} & \multicolumn{2}{|c|}{$\begin{array}{l}\text { Swift } \\
\text { trust }\end{array}$} & \multicolumn{2}{|c|}{$\begin{array}{c}\text { Time-based } \\
\text { trust }\end{array}$} & \multicolumn{2}{|c|}{$\begin{array}{l}\text { Multi- } \\
\text { faceted } \\
\text { trust }\end{array}$} & \multicolumn{2}{|c|}{$\begin{array}{l}\text { Dispositional } \\
\text { trust }\end{array}$} & \multicolumn{2}{|c|}{$\begin{array}{l}\text { Institution- } \\
\text { based trust }\end{array}$} & \multirow{2}{*}{$\begin{array}{c}\text { Total } \\
\mathrm{N} \\
\end{array}$} \\
\hline & $\mathrm{N}$ & $\%$ & $\mathrm{~N}$ & $\%$ & $\mathrm{~N}$ & $\%$ & $\mathrm{~N}$ & $\%$ & $\mathrm{~N}$ & $\%$ & $\mathrm{~N}$ & $\%$ & \\
\hline Communication & 7 & $11 \%$ & 3 & $12 \%$ & 3 & $13 \%$ & 2 & $6 \%$ & 1 & $14 \%$ & 2 & $20 \%$ & 18 \\
\hline $\begin{array}{l}\text { Computer } \\
\text { science }\end{array}$ & 18 & $27 \%$ & 8 & $32 \%$ & 7 & $29 \%$ & 9 & $26 \%$ & 0 & $0 \%$ & 0 & $0 \%$ & 42 \\
\hline $\begin{array}{l}\text { Information } \\
\text { systems }\end{array}$ & 16 & $24 \%$ & 6 & $24 \%$ & 6 & $25 \%$ & 11 & $32 \%$ & 3 & $43 \%$ & 5 & $50 \%$ & 47 \\
\hline Psychology & 8 & $12 \%$ & 3 & $12 \%$ & 1 & $4 \%$ & 2 & $6 \%$ & 0 & $0 \%$ & 0 & $0 \%$ & 14 \\
\hline Management & 17 & $26 \%$ & 5 & $20 \%$ & 7 & $29 \%$ & 10 & $29 \%$ & 3 & $43 \%$ & 3 & $30 \%$ & 45 \\
\hline Total & 66 & $100 \%$ & 25 & $100 \%$ & 24 & $100 \%$ & 34 & $100 \%$ & 7 & $100 \%$ & 10 & $100 \%$ & \\
\hline
\end{tabular}

Note. Theoretical and empirical manuscripts included. Some papers included multiple conceptualizations and are therefore represented more than once.

Table 1. Trust Conceptualization by Discipline of Journal

\subsubsection{Nature of Trust}

Overall, the view of trust in empirical VT studies is not as evolved as the conceptualizations of trust described in the broader theoretical writings about trust. That is, regardless of discipline, the approach to studying trust has been, at times, inconsistent with the underlying theorizing. First, the majority of the reviewed research focuses on trust as a generalized, static construct (see Table 2) even though more nuanced, dynamic views have been introduced in the broader trust literature. In a VT context, teams are viewed as constantly changing and evolving (Kozlowski, Chao, Grand, Braun, \& Kuljanin, 2013). The importance of team development suggests that interest in a temporal view incorporating time-based trust should be drastically increasing rather than stagnating, as it currently is. Second, theoretical work has shown a multi-faceted, nuanced view of trust. Yet, the rapid growth of generalized trust studies calls into question the impact theoretical work in the broader trust literature has had so far in informing the conduct of empirical studies about trust in VTs. Third, our review shows that more than a third of swift trust studies and the majority of time-based trust studies utilized intact student teams, calling into question if the methods are reflective of theory. These intact teams may not be accurately capturing the developmental process of trust nor swift trust as it exists from the team's inception. Consequently, researchers may not be appropriately operationalizing the testing of relationships with theory. In summary, the literature on trust in VTs to date explores trust by relying on static and generalized views of trust rather than richer, dynamic views of trust that may be more theoretically appropriate. 


\begin{tabular}{lcccccc} 
& \multicolumn{2}{c}{$\mathbf{2 0 0 3 - 2 0 0 8}$} & \multicolumn{2}{c}{$\mathbf{2 0 0 9 - 2 0 1 5}$} & \multicolumn{2}{c}{$\mathbf{2 0 0 3 - 2 0 1 5}$} \\
\cline { 2 - 8 } & $\mathrm{N}$ & $\%$ & $\mathrm{~N}$ & $\%$ & $\mathrm{~N}$ & $\%$ \\
\hline Generalized trust & 25 & $37 \%$ & 41 & $42 \%$ & 66 & $40 \%$ \\
\hline Swift trust & 13 & $19 \%$ & 12 & $12 \%$ & 25 & $15 \%$ \\
\hline Time-based trust & 11 & $16 \%$ & 13 & $13 \%$ & 24 & $14 \%$ \\
\hline Multi-faceted trust & 12 & $18 \%$ & 22 & $22 \%$ & 34 & $20 \%$ \\
\hline Dispositional trust & 3 & $4 \%$ & 4 & $4 \%$ & 7 & $4 \%$ \\
\hline Institution-based trust & 4 & $6 \%$ & 6 & $6 \%$ & 10 & $6 \%$ \\
\hline Total & 68 & $100 \%$ & 98 & $100 \%$ & 166 & $100 \%$ \\
\hline $\begin{array}{l}\text { Note. Theoretical and empirical manuscripts } \\
\text { multiple conceptualizations and are therefore represented more than once. }\end{array}$ \\
\hline
\end{tabular}

Table 2. Trust Conceptualization over Time

\subsubsection{Virtuality}

VTs are classified on the basis of their virtuality. In addition to its conceptualization, virtuality's operationalization has evolved over the past ten years. Initially, when researchers simply viewed teams as entirely virtual or face-to-face, virtuality was measured by whether or not technology supported the team. As noted in Appendix C, virtuality was often measured in this way or the measurement was not specified at all. New measures of virtuality reflect the nuanced, complex view of virtuality. For instance, O'Leary \& Cummings (2007) and Chudoba and colleagues (2005) developed indices to measure virtuality that permit researchers to document and measure the VT characteristics as well as study their impact with more precision. The findings of multiple studies could be compared more easily if the same indices of virtuality were employed. Despite efforts to develop indices, only eight studies have measured the dimensions of virtuality (Bierly, Stark, \& Kessler, 2009; Joshi et al., 2009; Lojeski, Reilly, \& Dominick, 2006; Lu et al., 2006; Morgan, Paucar-Caceres, \& Wright, 2014; Plotnick, Hiltz, \& Ocker, 2011; Staples \& Webster, 2008; Verburg et al., 2013). Hoch \& Kozlowski (2014) argued that not only must the dimensions of virtuality be incorporated into a composite operationalization, but that the precise contribution of each component should be determined. In summary, many of the reviewed studies view virtuality as the mere presence or absence of technology. Only recently have more nuanced views of virtuality been developed, yet few researchers employ these operationalizations.

\subsection{Antecedents of Trust}

More than half of the identified papers investigated the antecedents of trust formation and maintenance in VTs (see Appendix A). Given the importance of trust in interpersonal relationships, what creates or hinders trust represents a major issue in the research on VTs. We categorize these factors under member attributes (cultural distance, expertise), team structure (goals and roles, size, hierarchy, formalization), team management (leadership behaviours, leader characteristics), and interpersonal relations (familiarity, conflict). Trust appears to be created by knowledge of other team members' expertise (e.g., Dorairaj \& Noble, 2013). Further, trust is commonly found in teams with shared or aligned goals (e.g., Verburg et al., 2013), transformational leaders (e.g., Eom, 2009; Joshi et al., 2009), transactional leaders (e.g., Eom, 2009), participative leaders (Muganda \& Pillay, 2013) and well-defined goals as well as teams in organizations with more formalization (Al-Ani, Bietz, et al., 2013). On the 
other hand, cultural distance (Al-Ani, Bietz, et al., 2013; Al-Ani, Marczak, et al., 2013), a larger team size (Al-Ani, Marczak, et al., 2013; Al-Ani \& Redmiles, 2009a, 2009b), unprincipled VT leaders (e.g., Al-Ani, Marczak, et al., 2013), and conflict (e.g., Bierly et al., 2009) serve as barriers to creating trust in VTs. Specific findings about antecedents of trust in VT supporting these statements may be found in Appendix D.

\subsection{Consequences of Trust}

Fewer extant studies look at consequences of trust in VTs as compared to antecedents. For the purposes of this review, we followed accepted team frameworks and categorized consequences into the team categories of performance (relations between the group and the environmental context), member well-being (the development and maintenance of the group as a system), and member support (ways in which the individual is embedded within the group) (McGrath, 1991). Trust has been positively related to a number of types of performance including learning effectiveness (e.g., Edwards \& Sridhar, 2005), creative problem solving (e.g., Murthy, Rodriguez, \& Lewis, 2013), individual member performance and team performance (e.g., Sarker, Ahuja, Sarker, \& Kirkeby, 2011), especially as reported by the team members themselves (e.g., Peters \& Karren, 2009). Member well-being in the form of higher satisfaction and morale have also been linked to higher levels of trust (e.g., DeRosa, Hantula, Kock, \& D'Arcy, 2004). Research also suggests that member support in terms of cooperation is made possible by trust (e.g., Kanawattanachai \& Yoo, 2007), though it is often more difficult to achieve in VTs (e.g., Bierly et al., 2009). Trust is also linked to greater cohesion and less turnover in VTs (e.g., DeRosa et al., 2004).

A unique consequence that has been studied in the trust in VTs literature is overcoming failures due to technology use. A major benefit, but also a problem with VTs, is their reliance on various forms of technology. Inevitably, these forms of technology can fail and interrupt operations. Trust has been studied as a central part in VTs overcoming technological difficulties (Gaan, 2012). When trust is high, team members provide the benefit of doubt to other members when the technology fails (Gaan, 2012). For example, if something gets wrongly posted or sent through the technology, other members are not as offended. Further, Theory $Y$ leadership has been found to facilitate technology adoption which what in turn is linked to increased trust and better team outcomes (Thomas \& Bostrom, 2008). In addition to findings about antecedents, Appendix D also describes the findings about the consequences of trust in VTs.

\subsection{Moderators}

In contrast to the antecedents and consequences of trust, there is less information about the moderators of trust in VTs that strengthen, weaken, or nullify the relationships mentioned above. Approximately one fifth of the articles study a wide range of moderating relationships (i.e., 24 of 124). The literature, as shown in Appendix A, suggests that culture, task type, functional diversity, and task interdependence represent important moderating factors for how trust is formed and translated into outcomes (Eom, 2009; Furumo \& Pearson, 2006; Mukherjee, Hanlon, Kedia, \& Srivastava, 2012; Peters \& Karren, 2009). Only four articles suggest that virtuality is a moderator. However, research designs of virtuality based on the mere presence or absence of a technology like email may limit confidence in these findings. While important, moderating effects are generally underexplored, especially type of VT and task type (Hertel et al., 2005). 


\subsubsection{Technology Capabilities}

A range of technologies support VT communication and knowledge sharing (e.g., email, video conferencing). These technologies vary in the extent of their synchronicity and ability to convey cues, indicating aspects of the technology affect relationships in the trust in VT area (Dennis \& Valacich, 1999). Most articles do not explain differences in findings based upon technology used, with the exception of three approaches. First, the task-technology fit approach seeks to match the task with the technology (Goodhue \& Thompson, 1995; Zigurs \& Buckland, 1998). Research in the trust in VTs literature has relied on this approach to suggest things like technology fit enhances manager's choice of leadership styles (Thomas \& Bostrom, 2008). The second draws upon media synchronicity theory (Dennis \& Valacich, 1999) which proposes that the functionality of a communication medium can influence how an individual performs a task (Maruping \& Agarwal, 2004). Third, the design science approach proposes developing innovative artefacts to support trust building in VTs (Wu, Zhao, Vassileva, Sun, \& Fan, 2014). For example, based on a design science approach, Wu and colleagues (2014) compared wiki systems to optimize the design and implementation of systems handling team conflict and motivating collaborative learning. Additionally, Tarmizi and colleagues (2007) used the design science approach to design, develop, and test the feasibility of collaborative process engineering in virtual settings.

In all, these approaches unearth the finding that the type of technology is not uniformly better or worse. The technology, rather, needs to properly fit the situation and members of the team. For example, technologies that transmit visual and voice cues are most related to trust during early stages (Maruping \& Agarwal, 2004). Additionally, design science can more fully inform the proper design and implementation for technology in each context (Gregor \& Hevner, 2013; Hevner, March, Park, \& Ram, 2004). Technological tools are important, yet are a poorly studied variable in this literature.

\subsubsection{Processes}

In our sample, some processes such as communication, conflict resolution, knowledge sharing and exchange were discussed, but in a static manner. That is, most articles in our sample examine processes using a variance approach. They seek to predict or explain levels or degrees of trust based on the values of other variables, including variables measuring specific processes such as communication and knowledge sharing. Although such processes are seen as collections of pivotal actions, they are rarely treated as a dynamic process. Instead, most trust in VT studies consider them as either an antecedent of trust (e.g., Coppola, Hiltz, \& Rotter, 2004) or an outcome of trust (e.g., He \& Paul, 2008). These studies show that transferring knowledge using face-to-face communication is positively associated with trust (e.g., Dorairaj, Noble, \& Malik, 2012; Hambley et al., 2007) and that communication with technologies that most approximate face-to-face interaction foster trust since it allows for the transmission of social cues and other forms of knowledge (e.g., Dorairaj et al., 2012; Hambley et al., 2007). Moving to consequences, scholars have shown that trust positively impacts knowledge sharing (He \& Paul, 2008; Mital, Israel, \& Agarwal, 2010; Paul \& He, 2012; Staples \& Webster, 2008), information acceptance (Al-Ani, Wilensky, Redmiles, \& Simmons, 2011), and overall knowledge transfer levels (Kuo \& Yu, 2009; Monalisa et al., 2008; Newell, David, \& Chand, 2007a, 2007b). Yet, knowledge sharing is an ongoing process that evolves as trust also evolves. Considering it as both an antecedent and consequence of trust leads to confusion in how to properly operationalize the construct. 
Only a handful of studies adopt a process approach in which processes evolve together over time and can be captured in an overall temporal model. Most of these employ stage models from the management literature such as Tuckman's model of team development (Corbitt, Gardiner, \& Wright, 2004; Furst, Reeves, Rosen, \& Blackburn, 2004; Tseng \& Ku, 2011), Gersick's (1988, 1989) Theory of Punctuated Equilibrium (Kanawattanachai \& Yoo, 2007; McNab, Basoglu, Sarker, \& Yu, 2012), or Lewicki and Bunker's $(1995,1996)$ stages of multiphase trust (Gwebu, Wang, \& Troutt, 2007; Kuo \& Yu, 2009) to describe the relevant processes and conditions that lead to the development of trust in VTs over time. Others develop their own stages unique to VTs (Henttonen \& Blomqvist, 2005; Hertel et al., 2005; Suprateek Sarker \& Sahay, 2003; Zander et al., 2013). In these stage models, VTs form and proceed through distinct periods, which represent a gradual and logical development whereby teams finally achieve effective goal fulfillment. Trust development, in turn, can correspond to distinct stages of team development in a VT. In these studies, trust development and team development tend to run in parallel and few studies explain or test how these impact each other. For example, in Kuo \& Yu (2009), swift trust emerges as the team starts its project; calculus and knowledgebased trust emerge, gradually peak at the project midpoint and then wane; and a low-level of identification trust is displayed by team members at the project's end (see Appendix C). The stage models around which the trust in VT literature have coalesced have faced much criticism. Some weaknesses include: a) group actions typically proceed in iterative cycles not in a linear order (Fisher, 1970; Scheidel \& Crowell, 1964), b) there are many possible sequences of actions through which goals get accomplished in groups, not just one (Poole, 1981, 1983), and c) how groups conduct actions to accomplish goals is not a gradual and sequential process (Gersick, 1988).

\section{Discussion}

Based on our review, we present an integrated conceptual model of the nomological network of trust in VTs (Figure 1) that identifies antecedents, consequences, processes, technology capabilities and moderators of trust in VTs. This model represents the current state of the literature. While many organizations are already relying on VTs, emerging new forms of work, among them remote work and digital nomadism, will lead to "traditional" and "new types" of VTs to become even more prevalent in the workplace of the future. Consequently, team management, which is suggested as an antecedent of trust in VTs in our model, and specifically VT leaders, will have to find new strategies to create and reinforce trust in their teams so as to achieve and maintain team effectiveness. While advanced technological solutions supporting the work of VTs (e.g., by facilitating digital presence) are continuously released, building trust in VTs requires digital fluency (e.g., knowing when to use which tool) and effective (digital) leadership (Colbert, Yee, \& George, 2016; Henttonen \& Blomqvist, 2005; Thomas \& Bostrom, 2008; Zander et al., 2013).

Against this backdrop, in the following sections, we discuss future research that could address shortcomings in the existing literature and that could help effectively deal with issues in the workplace of the future. Additionally, to provide fresh insights into this area of study, we conclude with potential synergies across different disciplines dealing with trust in VTs and provide recommendations for the management of VTs in the changing new world of work. 


\subsection{Future Research to Address Gaps}

First, the focus on the dynamic nature in developing trust in VTs is lacking, representing a major gap. To transition from the static view found in much of the literature to a more dynamic view, it will require shifting from variance models that have been predominately used to process models (Markus \& Robey, 1988; Mohr, 1982). Variance models view constructs as independent variables (i.e., leadership behaviours, formalization) that cause change in the levels or degrees of dependent variables (i.e., trust) (Van de Ven \& Poole, 2005). These models assume that the basic character of the dependent variable is not changed and that the temporal sequence for triggering changes in the independent variable is immaterial (Van de Ven \& Poole, 2005). Process models, in contrast, assume that the basic nature of the dependent variable (i.e., trust) may change. For example, swift trust may be manifest at the beginning of a VT project whereas identification trust may emerge at the end. Process models recognize the complexity among events to account for temporal connections and the dynamic nature of processes (Marks, Mathieu, \& Zaccaro, 2001). More specifically, processes are conceptualized as interdependent actions that transform inputs (antecedents) to outputs (consequences) (Marlow, Lacerenza, \& Salas, 2017). They represent behaviours or actions (e.g., monitoring team-mates, motivating the team), which can be contrasted with emergent states, or properties of the team that arise through the dynamic team process interactions (e.g., collective efficacy, cohesion). Within this view, trust is seen as an emergent state that supports team processes and other important emergent states (Marlow et al, 2017). Further, process models focus on change over time and are interested in sequences of events (Burton-Jones et al., 2015) and the patterns of influence that must be applied to a development process (Van de Ven \& Poole, 2005). That is, a process model would describe trust development as a process encompassed by a set of actions (e.g., communication processes) that produces forms of trust (i.e., calculus trust, knowledge-based trust) as emergent states which further support team processes and emergent states. Within the view of process models, future studies could study technologies as intertwined with organizational processes or investigate how specific technologies or their features impact team processes (Gibbs et al., 2017) which affect trust states.

Second, our review suggests that IS researchers adopt only a limited number of conceptualizations of trust (e.g., focusing only on swift trust or generalized trust), resulting in a fragmented understanding of trust. As explained in more detail in our cross-disciplinary discussion (Section 5.2), future research should explore how different conceptualizations of trust interact with each other, especially across time.

Third, virtuality is sometimes conceptualized merely as the presence or absence of certain technologies. We encourage future researchers to pay particular attention to how they think about and operationalize virtuality. Doing so can enrich our understanding of the inconsistent findings about trust in VTs. For example, Joshi et al. (2009) found that inspirational (transformational) leadership is more important for team performance in VTs with higher degrees of virtuality as compared to teams with lower degrees of virtuality. Joshi and colleagues' (2009) operationalization of virtuality took into account multiple types of dispersion. Hambley et al. (2007) also looked at virtuality as a moderator, but found no moderating relationship between transformational leadership and team performance. However, for them virtuality was operationalized in terms of the nature of technology use (e.g., face-to-face only without any technology, videoconferencing and chat), as was common at the time. Was the lack of significant findings for Hambley et al. (2007) because there really is no relationship or because virtuality was measured poorly? Virtuality is a multidimensional 
construct. If across disciplines we can adopt one, or only a few, approaches to measuring these multiple dimensions of virtuality, we all will be in a better position to compare results and understand inconsistencies.

Fourth and finally, our review suggests that the existing literature may not be matching study design to theory: many scholars are using the wrong types of teams to study the different aspects of trust. For instance, if the primary interest is swift trust, researchers should investigate newly forming teams, as existing teams have likely passed this stage of trust development. Similarly, if the primary interest is in studying the development of time-based trust, researchers should employ longitudinal studies in long-term VTs and rely less heavily on student teams. In addition to longitudinal studies, multiple methods may need to be employed to gain insights about the development of various types of trust.

\subsection{A Cross-Disciplinary Discussion}

With the multi-disciplinary nature of our review, we hope that this effort starts a conversation across disconnected disciplines to improve the conceptualizations of trust and virtuality. Scholars are missing important contributions from other disciplines and we hope this distance between conversations can begin to close. For example, while psychology researchers recently framed a new and major contribution by operationalizing virtuality to include cultural differences (Hoch \& Kozlowski, 2014), IS researchers have proposed a cultural dimension to virtuality for more than a decade (e.g., Chudoba et al., 2005; Watson-Manheim, Chudoba, \& Crowston, 2002). IS research findings about how cultural differences impact trust (Al-Ani, Bietz, et al., 2013; Al-Ani \& Redmiles, 2009a, 2009b; Al-Ani, Redmiles, et al., 2013; Gaan, 2012; Krebs, Hobman, \& Bordia, 2006; Newell et al., 2007b; Paul \& He, 2012), VT processes, and outcomes are many (e.g., Pinjani \& Palvia, 2013; Scott, 2013). Further, psychology researchers' views of what makes a team virtual (i.e., teams with distant members who use email to communicate are compared to teams whose members are collocated) can be informed by the IS discipline's view of technology and virtuality. The IS discipline has assumed a leading role in exploring how technology affects team members. Thus, psychology researchers can benefit from utilizing existing IS research to better frame their study of VTs. Conversely, IS researchers need to explore the dynamic, multi-dimensional aspects of trust that are discussed in management and psychology journals.

Below are several sample synergies across disciplines that highlight strength that other researchers can leverage. It should be noted that our comments about disciplinary contributions are based on the discipline in which a particular article is published. We recognize that some cross-disciplinary publishing (e.g., psychologists publishing in management journals, IS researchers publishing in psychology journals) exists. This crossdisciplinary publishing can be viewed as healthy for cross-fertilizing ideas, and we hope it continues. The sample synergies below are by no means comprehensive but rather a starting point to further cross-disciplinary conversations.

\subsubsection{Is Swift Trust Informing Research on Different Kinds of Teams?}

IS researchers have largely focused on swift trust to inform research on VTs. However, swift trust was initially proposed for quick starting temporary teams (Meyerson et al., 1996). Swift trust is by no means constrained to only virtual environments, yet virtual environments have dominated its investigation. The rich empirical results from IS researchers can inform other kinds of team management that will be common in the work of the future. For example, there 
is a growing research body on swift starting action teams - highly interdependent teams of skilled individuals completing demanding and time-pressured projects - which have been proposed by psychology researchers as a unique type of team that faces a host of challenges not seen in traditional teams (Wildman et al., 2012). However, the research does not yet provide a clear picture of how trust develops in these environments. The IS research on swift trust can provide much insight. For example, is swift trust as fragile and temporary in these settings as in virtual environments? Can swift trust account for the starting level of trust in swift starting action teams?

\subsubsection{Management's Research to Inform an Understanding of 'Team' Trust}

Management research has several streams that can be applied to conceptualizing and studying 'team' trust. Management researchers have recently started to investigate the dispersion and accuracy of trust judgments, as well as multi-level trust. Trust is, at its nature, bidirectional where parties need to trust and be trusted when engaging in mutually beneficial exchanges (e.g., Korsgaard, Brower, \& Lester, 2015). Members at different organizational levels may have different perspectives on the kind of trust in a particular relationship. Several have pointed to a weakness of the trust literature as almost exclusively focusing on the one-sided trust of the trustor (Fulmer \& Gelfand, 2012). Some can levy this same claim on the trust in VTs research. Trust in VTs researchers can directly address this weakness by exploring trust as a bidirectional sequence that is networked among team members. Is this process of creating team trust transitive in nature such that when two team members develop trust it can be transferred to a third member? Or are there synergies in VT contexts that allow the development of a shared, team trust? It may be that the variance of trust perceptions is a stronger driver of team processes and outcomes. Trust in VTs researchers can leverage reciprocal, mutual, and asymmetric trust models to explore the trust development process in VTs (Tomlinson, Dineen, \& Lewicki, 2009). Teams researchers as a whole have not adopted this perspective (e.g., Korsgaard et al., 2015), and these trust accuracy perceptions are potentially even more important in higher-virtuality team environments. VT researchers of trust can also draw from management research that considers how trust can be conceptualized at both the individual and team levels, as well as how trust may be aggregated from the individual to team level (Fulmer \& Gelfand, 2012).

\subsubsection{Impact of Technology Use on Trust Development in Higher-Virtuality Teams}

IS-based media synchronicity theory (Dennis \& Valacich, 1999; Dennis, Fuller, \& Valacich, 2008) suggests that communication technologies can be placed along a continuum of low to high synchronicity based on a number of factors (i.e., transmission velocity, symbol sets, parallelism, rehearsability, and reprocessability). Technologies that are high in synchronicity can build higher levels of trust (Dorairaj et al., 2012; Hambley et al., 2007) and converge on meaning (Dennis et al., 2008; Maruping \& Agarwal, 2004). High synchronicity technologies that facilitate the convergence of meaning are important for quickly moving beyond swift trust to deeper forms of trust. This is because initial swift trust judgments give way to verification and perceptions of shared meaning (Dennis et al., 2008). Once teams evolve into deeper forms of trust, different aspects of the technologies that are used become important. For example, in knowledge-based trust, a type of time-based trust (see Appendix B), team members gain deep knowledge about other team members and are better able to anticipate their responses and reactions (Lewicki et al., 2006). As members acquire a deep knowledge of the others in their VT, they can move past communication failures by more easily anticipating what the other 
team member had meant, even when technologies that are low in synchronicity are used. All disciplines could consider media synchronicity as a means of improving deficiencies in highervirtuality teams. Kirkman and Mathieu's (2005) view of virtuality based on technology that is employed in the management literature may further help enrich this line of study.

\subsection{Managing Virtual Teams in the Technology-driven Workplace of the Future}

Though VTs have been prevalent in the workplace, many challenges remain in managing them effectively. Our review helped surface ways of building trust to deal with some of these challenges. In this section we describe the guidelines we found, as well as challenges related to VTs that we anticipate in the workplace of the future.

\subsubsection{Creating and Maintaining Trust over a VT's Lifespan by Using Virtual Technologies}

Given the ubiquity of VTs, it is important to find ways of making them more effective in future workplaces. Building trust in VTs certainly seems to be a viable way of doing so. As shown in our review above, VTs with higher levels of trust produce high quality products (e.g., Altschuller \& Benbunan-Fich, 2010; He \& Paul, 2008; Jarvenpaa, Shaw, \& Staples, 2004) and are more creative (Murthy et al., 2013). Further, VTs with participative (Henttonen \& Blomqvist, 2005; Muganda \& Pillay, 2013) and inspirational leadership (Joshi et al., 2009) are reported to have higher performance.

Our review of the literature further suggests that timing is critical in building trust in VTs. When no other option is available, managers of VTs must rely on swift trust. It is encouraging that teams can start with some form of trust. However, managers should take steps early in the life of their VTs to develop deeper forms of trust. One option is to arrange face-to-face team building meetings where the team members share information about their training and abilities to move to deeper forms of trust (Zander et al., 2013). Beyond this, managers could allow team members access to this information through a company wiki or internal website. In this regard, using an internal social networking site, i.e. an Enterprise Social Network (ESN), might be particularly suitable to reinforce trust development processes in VTs by facilitating the building of a shared context (Riemer \& Scifleet, 2012). Following updates and discussing matters of interest, employees become aware of happenings in the organization and get to know each other. In the course of these interactions, a shared background emerges that can be considered as an important prerequisite for trust. Also, technologies such as shared visualizations (Weakley \& Edmonds, 2004) or the application of agile techniques (Karagoz, Korthaus, \& Augar, 2016) facilitate collaboration, knowledge sharing, and trust between members of distributed teams.

Managers of VTs should also turn to team training explicitly designed to build trust in their teams (Lukić \& Vračar, 2018). Team training can address team breakdowns and expand team capabilities. Providing teams opportunities to a) learn teamwork-focused knowledge, skills, and attitudes (as compared to task-focused training), b) practice working together, and c) receive feedback for improving team interactions can provide teams with a deeper understanding of teammates for facilitating trust development, and create a "toolbox" for overcoming challenges associated with virtuality. Individualized training may also be helpful. Team members can benefit from one-on-one coaching from their team leaders about their performance and the team's mission (Watkins, 2013). And, team leaders can be trained on managing VTs, especially culturally diverse VTs. It appears that self-identified leaders of VTs believe they are better prepared to lead culturally-diverse teams than do those who are 
members of their teams. That is, a high percentage of self-identified leaders (i.e., $96 \%$ ) rate themselves as either effective or highly effective in managing across cultures and countries, yet $58 \%$ of respondents indicate that global team leaders are not adequately prepared to lead multicultural teams ( $\mathrm{RW}^{3}$ CultureWizard, 2016).

Once VTs are formed, managers can alter schedules to ensure synchronous meetings, perhaps via Skype or videoconferencing. The time of these remote synchronous meetings can be rotated across time zones (RW ${ }^{3}$ CultureWizard, 2016). These meetings can be held on a regular basis to develop time-based trust. Interestingly, too many meetings may be a symptom of lack of trust since different levels of managers and employees may not trust one another (Al-Ani, Marczak, et al., 2013). Because technology is so intrinsic to the definition of VTs, VT managers can leverage the technology to their benefit. Still, the timing of technology use is important. For example, technologies high in synchronicity may be particularly important early in the trust development cycle while technologies low in synchronicity may be more important later in the cycle.

In order to enhance team effectiveness, managers of VTs may need to develop and leverage electronic Transactive Memory Systems (TMSs), or systems for storing, encoding and retrieving knowledge related to team activities, and member skills and expertise. Beyond supporting trust formation in early stages of VTs, the above-mentioned ESN platforms can be used for this purpose. Later in trust development cycles, higher-virtuality teams may hold an advantage over low-virtuality teams as they have electronic TMSs. Higher-virtuality teams can automatically store discussions about activities and decisions in messages streams, e.g., within dedicated groups of an ESN, email conversations, or other electronic storage. Of course, teams also may have TMSs residing as overlapping mental representations in the minds of its members. When teams have well-developed TMSs, the team members have stored knowledge about how to perform necessary tasks that have been performed before and whom to contact to do subtasks. Kanawattanachai and Yoo (2007) suggest that forms of trust work together with team members' knowledge of others' expertise to promote highly developed TMSs and more effective team performance. Thus, managers should develop norms encouraging the use of ESN messages or emails to confirm team decisions and to set up wikis, blackboards or other electronic repositories for key documents to enhance the team's TMS. By properly designing when team members can use which technology, VT managers can improve the trust development process in highly virtual teams.

\subsubsection{Dealing with Workplace Trends Affecting Trust Formation in VTs}

As the workplace changes, managers must consider the impact of trends on trust development in VTs. In particular, increased use and emphasis on multiteam systems, work/life balance, and technologies like robotics are important trends for HR practitioners and VT managers to consider.

Multiteam systems involve multiple specialized groups working together interdependently to accomplish organizations' goals or complete IS programs (Firth, Hollenbeck, Miles, Ilgen, \& Barnes, 2015; Mathieu, Marks, \& Zaccaro, 2001). Such systems add another level of complexity to trust building - amplifying the challenges to coordination and communication (van Knippenberg, Dahlander, Haas, \& George, 2015). In terms of interorganizational relationships, Lane \& Lum (2011) and Flemming \& Low (2007) argue that trust and a shared business understanding are key drivers of partnership quality in IT outsourcing arrangements. As for multiteam systems, it is likely that there are different levels of trust involved (i.e., interpersonal, group, 
organizational) and trust at the multiteam system level likely has some characteristics that differ from trust at other levels.

Another current topic of interest and one that is likely to assume even greater significance for members of the workforce of the future is work-life balance. Work-life balance is the state when work-family conflict (which occurs when the demands from one set of roles interferes with the completion of the demands from another set of roles) is considered to be at an acceptable level (Rutkowski \& Saunders, 2018). However, work-family conflict is common if one is always working. Modern ICT have virtually "eliminated the conventional workday and have made time and distance immaterial to the execution of many organizational tasks" (Ragu-Nathan, Tarafdar, Ragu-Nathan, \& Tu, 2008, pg. 418). On the positive side, ICT support VTs. However, they also can blur the boundaries between work and family and leave team members feeling that they must available to VT teammates on a 24/7 basis. One question that might be explored is the extent to which team members can build trust in other members if they perceive that they must constantly respond to communications from them even if it conflicts with their family time. Governments have tried to ameliorate work/life imbalance with campaigns and legislation. For example, the French government passed legislation in 2017 which "requires companies with more than 50 employees to establish hours when staff should not send or answer emails" (Morris, 2017), thus granting employees the right to "switch off" after hours. However, as well-meaning as it is meant to be, the French legislation could create considerable conflict for employees who work on global VTs. Unless the members have a considerable level of trust, the employees who are quite distant from France might not appreciate their French teammates "switching off" their calls, emails or other communications. Here it is important for team leaders must build trust among the remote members to reduce their stress while keeping them in the communication loop (Staples, 1997).

Finally, another trend that is changing the nature of the workforce of the future is its inclusion of robots. The cost of robots is dropping concomitantly with the increase in their abilities to perform a wide range of tasks with great efficiency, accuracy, and reliability. Industrial robots that are being used in "dangerous, dirty or dull" jobs represent a forecasted market of \$37 billion by 2018 (Goodman, 2015). In addition, robots are becoming "collaborative" to the extent that they are now safer for their human colleagues to work with and relationships between owners, workers and robots on the assembly line are carefully choreographed (Tingley, 2017). It is conceivable that robots might join VTs and eventually provide "high level functions as fullfledged team members" (Hancock et al., 2011, pg. 517). In ensuing human-robot collaborative teams, humans on the team must learn to trust their robotic teammates to protect their welfare and interests. They need to accept the robot as it was designed to perform, but must make sure that the level of trust in the robot is appropriate (Oleson, Billings, Kocsis, Chen, \& Hancock, 2011). Future research should explore what factors impact the development and maintenance on human-robot VTs.

\subsection{Limitations}

In conducting our review, we were challenged with balancing the time available to us with the need to have an adequate level of coverage (vom Brocke et al., 2015). Thus, we developed rules for what would be included and excluded from our review and systematically applied them. We decided to base our selection on the title, abstract and keywords, and not the whole text (vom Brocke et al., 2015) and on a search of databases and not just journals (Webster \& Watson, 2002). Not searching the full text for key terms or not focusing on specific journals, such as the 
Senior Scholar Basket of Journals, no doubt meant that we missed some relevant articles, albeit, we did so systematically. Another limitation that could be levied against our study is that we only searched on 'trust' and 'swift trust', but not other types of trust. However, our search for articles on 'trust' unearthed studies with other types of trust such as the five other types of trust that we ended up discussing. Further, we did not search on other possible names of VTs such as geographic-dispersed teams, remote team or computer-mediated teams, though articles with these titles often surfaced on our search and we included them.

\subsection{Conclusion}

Overall, organizations are increasingly relying on VTs despite the challenges found in virtual structures, which are characterized by high levels of technology use. This change in work represents an opportunity for research to inform practice. Research exploring trust in this growing organizational form has, similarly, exploded. We, accordingly, conduct a multidisciplinary theoretical review of the trust in VT literature to show its role in addressing these VT challenges and those that are likely to gain prominence in the workforce of the future. Our integrated model of trust in VTs helps identify important antecedents, consequences, and other constructs that are critical in building and experiencing trust in VTs. Despite the powerful nature of trust, our review uncovered several important weaknesses in the literature that must be overcome to move forward - namely, problematic conceptualizations of trust and virtuality. We highlight these weaknesses and suggest how research across disciplines can be used to start healthy multidisciplinary dialogue and to create better conceptualizations for theorizing and conducting research on trust in VTs. We hope that researchers will take up our call to incorporate the improved conceptualizations of trust and virtuality in order not only to improve the prospects of the work-force today effectively using technology in their VTs, but also the workforce of the future.

\section{References}

Al-Ani, B., Bietz, M. J., Wang, Y., Trainer, E., Koehne, B., Marczak, S., Redmiles, D., Prikladnicki, R. (2013). Globally distributed system developers. In Proceedings of the 2013 conference on Computer supported cooperative work - CSCW'13 (p. 563). New York, New York, USA: ACM Press. https://doi.org/10.1145/2441776.2441840

Al-Ani, B., Marczak, S., Prikladnicki, R., \& Redmiles, D. (2013). Revisiting the Factors that Engender Trust of Global Systems Engineers. In 2013 IEEE 8th International Conference on Global Software Engineering (pp. 31-40). IEEE. https://doi.org/10.1109/ICGSE.2013.13

Al-Ani, B., Marczak, S., Redmiles, D., \& Prikladnicki, R. (2014). Facilitating contagion trust through tools in Global Systems Engineering teams. Information and Software Technology, 56(3), 309-320. https://doi.org/10.1016/j.infsof.2013.11.001

Al-Ani, B., \& Redmiles, D. (2009a). In Strangers We Trust? Findings of an Empirical Study of Distributed Teams. In 2009 Fourth IEEE International Conference on Global Software Engineering (pp. 121-130). IEEE. https://doi.org/10.1109/ICGSE.2009.20

Al-Ani, B., \& Redmiles, D. (2009b). Supporting Trust in Distributed Teams through Continuous Coordination. IEEE Software. https://doi.org/10.1109/MS.2009.115

Al-Ani, B., \& Redmiles, D. (2009c). Trust in Distributed Teams: Support through Continuous Coordination. IEEE Software, 26(6), 35-40. https://doi.org/10.1109/MS.2009.192 
Al-Ani, B., Redmiles, D., de Souza, C. R. B., Prikladnicki, R., Marczak, S., Lanubile, F., \& Calefato, F. (2013). Trust in virtual teams. In Proceedings of the 2013 conference on Computer supported cooperative work companion - CSCW '13 (pp. 301-306). New York, New York, USA: ACM Press. https://doi.org/10.1145/2441955.2442029

Al-Ani, B., Wilensky, H., Redmiles, D., \& Simmons, E. (2011). An Understanding of the Role of Trust in Knowledge Seeking and Acceptance Practices in Distributed Development Teams. In 2011 IEEE Sixth International Conference on Global Software Engineering (pp. 2534). IEEE. https://doi.org/10.1109/ICGSE.2011.25

Altschuller, S., \& Benbunan-Fich, R. (2010). Trust, Performance, and the Communication Process in Ad Hoc Decision-Making Virtual Teams. Journal of Computer-Mediated Communication, 16(1), 27-47. https://doi.org/10.1111/j.1083-6101.2010.01529.x

Altschuller, S., \& Benbunan-Fich, R. (2013). The pursuit of trust in ad hoc virtual teams: how much electronic portrayal is too much? European Journal of Information Systems, 22(6), 619-636. https://doi.org/10.1057/ejis.2012.39

Aubert, B. A., \& Kelsey, B. L. (2003). Further Understanding of Trust and Performance in Virtual Teams. Small Group Research, 34(5), 575-618. https://doi.org/10.1177/1046496403256011

Bartelt, V. L., \& Dennis, A. R. (2014). Nature and Nurture: The Impact of Automaticity and the Structuration of Communication on Virtual Team Behavior and Performance. MIS Quarterly, 38(2), 521-538. https://doi.org/10.25300/MISQ/2014/38.2.09

Baskerville, R., \& Nandhakumar, J. (2007). Activating and Perpetuating Virtual Teams: Now That We're Mobile, Where Do We Go? IEEE Transactions on Professional Communication, 50(1), 17-34. https://doi.org/10.1109/TPC.2006.890849

Beranek, P. M. (2005). A Comparison of Relational and Trust Training Techniques for Virtual Team Communication: How Much Training is Enough? In Proceedings of the 38th Annual Hawaii International Conference on System Sciences. IEEE. https://doi.org/10.1109/HICSS.2005.5

Bierly, P. E., Stark, E. M., \& Kessler, E. H. (2009). The Moderating Effects of Virtuality on the Antecedents and Outcome of NPD Team Trust. Journal of Product Innovation Management, 26(5), 551-565. https://doi.org/10.1111/j.1540-5885.2009.00680.x

Bosch-Sijtsema, P. (2007). The Impact of Individual Expectations and Expectation Conflicts on Virtual Teams. Group \& Organization Management, 32(3), 358-388. https://doi.org/10.1177/1059601106286881

Brahm, T., \& Kunze, F. (2012). The role of trust climate in virtual teams. Journal of Managerial Psychology, 27(6), 595-614. https://doi.org/10.1108/02683941211252446

Breu, K., \& Hemingway, C. J. (2004). Making organisations virtual: the hidden cost of distributed teams. Journal of Information Technology, 19(3), 191-202. https://doi.org/10.1057/palgrave.jit.2000018

Brown, H. G., Poole, M. S., \& Rodgers, T. L. (2004). Interpersonal Traits, Complementarity, and Trust in Virtual Collaboration. Journal of Management Information Systems, 20(4), 115-138. https://doi.org/10.1080/07421222.2004.11045785 
Burton-Jones, A., McLean, E. R., \& Monod, E. (2015). Theoretical perspectives in IS research: from variance and process to conceptual latitude and conceptual fit. European Journal of Information Systems, 24(6), 664-679. https://doi.org/10.1057/ejis.2014.31

Chang, H. H., Chuang, S.-S., \& Chao, S. H. (2011). Determinants of cultural adaptation, communication quality, and trust in virtual teams' performance. Total Quality $\begin{array}{llll}\text { Management } \mathcal{E} \quad \text { Business } & \text { Excellence, 22(3), 305-329. }\end{array}$ https://doi.org/10.1080/14783363.2010.532319

Chang, H. H., Hung, C.-J., \& Hsieh, H.-W. (2014). Virtual teams: cultural adaptation, communication quality, and interpersonal trust. Total Quality Management $\mathcal{E}$ Business Excellence, 25(11-12), 1318-1335. https://doi.org/10.1080/14783363.2012.704274

Chatfield, A. T., Shlemoon, V. N., Redublado, W., \& Darbyshire, G. (2014). Creating Value through Virtual Teams: A Current Literature Review. Australasian Journal of Information Systems, 18(3). https://doi.org/10.3127/ajis.v18i3.1104

Cheng, X., Macaulay, L., \& Zarifis, A. (2013). Modeling individual trust development in computer mediated collaboration: A comparison of approaches. Computers in Human Behavior, 29(4), 1733-1741. https://doi.org/http://dx.doi.org/10.1016/j.chb.2013.02.018

Cheng, X., Nolan, T., \& Macaulay, L. (2013). Don't give up the community: a viewpoint of trust development in online collaboration. Information Technology \& People, 26(3), 298-318. https://doi.org/10.1108/ITP-10-2012-0116

Chudoba, K. M., Wynn, E., Lu, M., \& Watson-Manheim, M. B. (2005). How virtual are we? Measuring virtuality and understanding its impact in a global organization. Information Systems Journal, 15(4), 279-306. https://doi.org/10.1111/j.1365-2575.2005.00200.x

Clark, W. R., Clark, L. A., \& Crossley, K. (2010). Developing multidimensional trust without touch in virtual teams. Marketing Management Journal, 20(1), 177-193.

Colbert, A., Yee, N., \& George, G. (2016). The Digital Workforce and the Workplace of the Future. Academy of Management Journal, 59(3), 731-739. https://doi.org/10.5465/amj.2016.4003

Collins, N., \& Chou, Y.-M. (2013). Building team trust: A study in the Asian context. Journal of American Business Review, Cambridge, 1(2), 181-188.

Coppola, N. W., Hiltz, S. R., \& Rotter, N. G. (2004). Building Trust in Virtual Teams. IEEE Transactions on Professional Communication, 47(2), 95-104. https://doi.org/10.1109/TPC.2004.828203

Corbitt, G., Gardiner, L. R., \& Wright, L. K. (2004). A comparison of team developmental stages, trust and performance for virtual versus face-to-face teams. In 37th Annual Hawaii International Conference on System Sciences, 2004. Proceedings of the. IEEE. https://doi.org/10.1109/HICSS.2004.1265157

Crisp, C. B., \& Jarvenpaa, S. L. (2013). Swift Trust in Global Virtual Teams. Journal of Personnel Psychology, 12(1), 45-56. https://doi.org/10.1027/1866-5888/a000075

Curşeu, P. L., Schalk, R., \& Wessel, I. (2008). How do virtual teams process information? A literature review and implications for management. Journal of Managerial Psychology, 23(6), 628-652. https://doi.org/10.1108/02683940810894729 
D. Olson, J., D. Appunn, F., A. McAllister, C., K. Walters, K., \& Grinnell, L. (2014). Webcams and virtual teams: an impact model. Team Performance Management: An International Journal, 20(3/4), 148-177. https://doi.org/10.1108/TPM-05-2013-0013

de Laat, P. B. (2005). Trusting Virtual Trust. Ethics and Information Technology, 7(3), 167-180. https://doi.org/10.1007/s10676-006-0002-6

Dennis, A. R., Robert, L. P., Curtis, A. M., Kowalczyk, S. T., \& Hasty, B. K. (2012). Research Note -Trust Is in the Eye of the Beholder: A Vignette Study of Postevent Behavioral Controls' Effects on Individual Trust in Virtual Teams. Information Systems Research, 23(2), 546-558. https://doi.org/10.1287/isre.1110.0364

Dennis, A. R., \& Valacich, J. S. (1999). Rethinking Media Richness: Towards a Theory of Media Synchronicity. In Proceedings of the 32nd Hawaii International Conference on System SciencesVolume 1 - Volume 1 (pp. 1017-1027). IEEE.

Dennis, Fuller, \& Valacich. (2008). Media, Tasks, and Communication Processes: A Theory of Media Synchronicity. MIS Quarterly, 32(3), 575. https://doi.org/10.2307/25148857

DeRosa, D. M., Hantula, D. A., Kock, N., \& D'Arcy, J. (2004). Trust and leadership in virtual teamwork: A media naturalness perspective. Human Resource Management, 43(2-3), 219232. https://doi.org/10.1002/hrm.20016

Dorairaj, S., \& Noble, J. (2013). Agile Software Development with Distributed Teams: Agility, Distribution and Trust. In 2013 Agile Conference (pp. 1-10). IEEE. https://doi.org/10.1109/AGILE.2013.7

Dorairaj, S., Noble, J., \& Malik, P. (2012). Understanding lack of trust in distributed agile teams: a grounded theory study. In 16th International Conference on Evaluation $\mathcal{E}$ Assessment in Software Engineering (EASE 2012) (pp. 81-90). https://doi.org/10.1049/ic.2012.0011

Edwards, H. K., \& Sridhar, V. (2005). Analysis of Software Requirements Engineering Exercises in a Global Virtual Team Setup. Journal of Global Information Management, 13(2), 21-41. https://doi.org/10.4018/jgim.2005040102

El Khatib, V., Trang, S., Reimers, K., \& Kolbe, L. (2013). The Role Of Motivational Factors in Distributed Software Development Teams: An Empirical Investigation. In Proceedings of the 21st European Conference on Information Systems.

Eom, M. (2009). Cross-Cultural Virtual Team and Its Key Antecedents to Success. Journal of Applied Business \& Economics, 10(1), 11-24.

Erez, M., Lisak, A., Harush, R., Glikson, E., Nouri, R., \& Shokef, E. (2013). Going Global: Developing Management Students' Cultural Intelligence and Global Identity in Culturally Diverse Virtual Teams. Academy of Management Learning E Education, 12(3), 330-355. https://doi.org/10.5465/amle.2012.0200

Fiol, C. M., \& O'Connor, E. J. (2005). Identification in Face-to-Face, Hybrid, and Pure Virtual Teams: Untangling the Contradictions. Organization Science, 16(1), 19-32. https://doi.org/10.1287/orsc.1040.0101

Firth, B. M., Hollenbeck, J. R., Miles, J. E., Ilgen, D. R., \& Barnes, C. M. (2015). Same Page, Different Books: Extending Representational Gaps Theory to Enhance Performance in 
Multiteam Systems. Academy of Management Journal, 58(3), 813-835. https://doi.org/10.5465/amj.2013.0216

Fisher, B. A. (1970). Decision emergence: Phases in group decision-making. Speech Monographs, 37(1), 53-66. https://doi.org/10.1080/03637757009375649

Flemming, R., \& Low, G. (2007). Information Systems Outsourcing Relationship Model. Australasian Journal of Information Systems, 14(2). https://doi.org/10.3127/ajis.v14i2.472

Fuller, C. M., Marett, K., \& Twitchell, D. P. (2012). An Examination of Deception in Virtual Teams: Effects of Deception on Task Performance, Mutuality, and Trust. IEEE Transactions on Professional Communication, 55(1), 20-35. https://doi.org/10.1109/TPC.2011.2172731

Fulmer, C. A., \& Gelfand, M. J. (2012). At What Level (and in Whom) We Trust. Journal of Management, 38(4), 1167-1230. https://doi.org/10.1177/0149206312439327

Furst, S. A., Reeves, M., Rosen, B., \& Blackburn, R. S. (2004). Managing the life cycle of virtual teams. Academy of Management Executive, 18(2), 6-20. https://doi.org/10.5465/AME.2004.13837468

Furumo, K., \& Pearson, J. M. (2006). An Empirical Investigation of How Trust, Cohesion, and Performance Vary in Virtual and Face-to-Face Teams. In Proceedings of the 39th Annual Hawaii International Conference on System Sciences (HICSS'06) (Vol. 00, p. 26c-26c). IEEE. https://doi.org/10.1109/HICSS.2006.51

Furumo, K., \& Pearson, J. M. (2007). Gender-Based Communication Styles, Trust, and Satisfaction in Virtual Teams. Journal of Information, Information Technology, and Organizations, 2, 47-60.

Gaan, N. (2012). Collaborative tools and virtual team effectiveness: An inductively derived approach in India's software sector. Decision, 39(1), 5-27.

Gao, S., Guo, Y., \& Chen, J. (2014). The Performance of Knowledge Collaboration in Virtual Teams: An Empirical Study. International Journal of Multimedia and Ubiquitous Engineering, 9(8), 193-212. https://doi.org/10.14257/ijmue.2014.9.8.17

Gartner. (2012). PPM \& IT Governance Summit [Brochure]. Retrieved January 13, 2017, from http://imagesrv.gartner.com/summits/docs/na/programmanagement/PPMIT4_Brochure.pdf

Germain, M.-L., \& McGuire, D. (2014). The Role of Swift Trust in Virtual Teams and Implications for Human Resource Development. Advances in Developing Human Resources, 16(3), 356-370. https://doi.org/10.1177/1523422314532097

Gersick, C. J. G. (1988). Time and Transition in Work Teams: Toward a New Model of Group Development. Academy of Management Journal, 31(1), 9-41. https://doi.org/10.2307/256496

Gersick, C. J. G. (1989). Marking Time: Predictable Transitions in Task Groups. Academy of Management Journal, 32(2), 274-309. https://doi.org/10.2307/256363

Gibbs, J. L., Sivunen, A., \& Boyraz, M. (2017). Investigating the impacts of team type and design on virtual team processes. Human Resource Management Review. https://doi.org/10.1016/j.hrmr.2016.12.006 
Gibson, C. B., \& Gibbs, J. L. (2006). Unpacking the Concept of Virtuality: The Effects of Geographic Dispersion, Electronic Dependence, Dynamic Structure, and National Diversity on Team Innovation. Administrative Science Quarterly, 51(3), 451-495. https://doi.org/10.2189/asqu.51.3.451

Gilson, L. L., Maynard, M. T., Jones Young, N. C., Vartiainen, M., \& Hakonen, M. (2015). Virtual Teams Research: 10 Years, 10 Themes, and 10 Opportunities. Journal of Management, 41(5), 1313-1337. https://doi.org/10.1177/0149206314559946

Giustiniano, L., \& Bolici, F. (2012). Organizational trust in a networked world. Journal of Information, Communication and Ethics in Society, 10(3), 187-202. https://doi.org/10.1108/14779961211261076

Goodhue, D. L., \& Thompson, R. L. (1995). Task-Technology Fit and Individual Performance. MIS Quarterly, 19(2), 213-236. https://doi.org/10.2307/249689

Goodman, M. (2015). Future crimes: Everything is connected, everyone is vulnerable and what we can do about it. London: Bantam Press.

Gregor, S., \& Hevner, A. R. (2013). Positioning and Presenting Design Science Research for Maximum Impact. MIS Quarterly, 37(2), 337-355. https://doi.org/10.25300/MISQ/2013/37.2.01

Gressgård, L. J. (2011). Virtual Team Collaboration and Innovation in Organizations. Team Performance Management: An International Journal, 17(1/2), 102-119. https://doi.org/10.1108/13527591111114738

Gwebu, K. L., Wang, J., \& Troutt, M. D. (2007). A Conceptual Framework for Understanding Trust Building and Maintenance in Virtual Organizations. Journal of Information Technology Theory and Application, 9(1), 43-63.

Haines, R. (2014). Group development in virtual teams: An experimental reexamination. Computers in Human Behavior, 39, 213-222. https://doi.org/10.1016/j.chb.2014.07.019

Hambley, L. A., O'Neill, T. A., \& Kline, T. J. B. (2007). Virtual Team Leadership. International Journal of E-Collaboration, 3(1), 40-64. https://doi.org/10.4018/jec.2007010103

Hancock, P. A., Billings, D. R., Schaefer, K. E., Chen, J. Y. C., de Visser, E. J., \& Parasuraman, R. (2011). A Meta-Analysis of Factors Affecting Trust in Human-Robot Interaction. Human Factors: The Journal of the Human Factors and Ergonomics Society, 53(5), 517-527. https://doi.org/10.1177/0018720811417254

He, F., \& Paul, S. (2008). An Empirical Investigation of the Roles of Outcome Controls and Psychological Factors in Collaboration Technology Supported Virtual Teams. In Proceedings of the 41st Annual Hawaii International Conference on System Sciences (HICSS 2008) (pp. 35-35). IEEE. https://doi.org/10.1109/HICSS.2008.51

Henttonen, K., \& Blomqvist, K. (2005). Managing distance in a global virtual team: the evolution of trust through technology-mediated relational communication. Strategic Change, 14(2), 107-119. https://doi.org/10.1002/jsc.714

Hertel, G., Geister, S., \& Konradt, U. (2005). Managing virtual teams: A review of current empirical research. Human Resource Management Review, 15(1), 69-95. https://doi.org/10.1016/j.hrmr.2005.01.002 
Hevner, A. R., March, S. T., Park, J., \& Ram, S. (2004). Design science in information systems research. MIS Quarterly, 28(1), 75-105.

Hoch, J. E., \& Dulebohn, J. H. (2017). Team personality composition, emergent leadership and shared leadership in virtual teams: A theoretical framework. Human Resource Management Review, 27(4), 678-693. https://doi.org/10.1016/j.hrmr.2016.12.012

Hoch, J. E., \& Kozlowski, S. W. J. (2014). Leading virtual teams: Hierarchical leadership, structural supports, and shared team leadership. Journal of Applied Psychology, 99(3), 390403. https://doi.org/10.1037/a0030264

Hunsaker, P. L., \& Hunsaker, J. S. (2008). Virtual teams: a leader's guide. Team Performance Management: An International Journal, 14(1/2), 86-101. https://doi.org/10.1108/13527590810860221

Jang, C.-Y. (2013). Facilitating Trust in Virtual Teams: The Role of Awareness. Advances in Competitiveness Research, 21(1-2), 61-77.

Jarvenpaa, S. L., Knoll, K., \& Leidner, D. E. (1998). Is Anybody out There? Antecedents of Trust in Global Virtual Teams. Journal of Management Information Systems, 14(4), 29-64.

Jarvenpaa, S. L., \& Leidner, D. E. (1998). Communication and Trust in Global Virtual Teams. Journal of Computer-Mediated Communication, 3(4). https://doi.org/10.1111/j.10836101.1998.tb00080.x

Jarvenpaa, S. L., \& Leidner, D. E. (1999). Communication and Trust in Global Virtual Teams. Organization Science, 10(6), 791-815. https://doi.org/10.1111/j.1083-6101.1998.tb00080.x

Jarvenpaa, S. L., Shaw, T. R., \& Staples, D. S. (2004). Toward Contextualized Theories of Trust: The Role of Trust in Global Virtual Teams. Information Systems Research, 15(3), 250-267. https://doi.org/10.1287/isre.1040.0028

Jensen, R. E. (2014). Why Closely Coupled Work Matters in Global Software Development. In Proceedings of the 18th International Conference on Supporting Group Work - GROUP '14 (pp. 24-34). New York, New York, USA: ACM Press. https://doi.org/10.1145/2660398.2660425

Jimenez, A., Boehe, D. M., Taras, V., \& Caprar, D. V. (2017). Working Across Boundaries: Current and Future Perspectives on Global Virtual Teams. Journal of International Management, 23(4), 341-349. https://doi.org/10.1016/j.intman.2017.05.001

Joshi, A., Lazarova, M. B., \& Liao, H. (2009). Getting Everyone on Board: The Role of Inspirational Leadership in Geographically Dispersed Teams. Organization Science, 20(1), 240-252. https://doi.org/10.1287/orsc.1080.0383

Kanawattanachai, \& Yoo. (2007). The Impact of Knowledge Coordination on Virtual Team Performance over Time. MIS Quarterly, 31(4), 783-808. https://doi.org/10.2307/25148820

Karagoz, Y., Korthaus, A., \& Augar, N. (2016). How do ICT project managers manage project knowledge in the public sector? An empirical enquiry from the Victorian Public Sector in Australia. Australasian Journal of Information Systems, 20. https://doi.org/10.3127/ajis.v20i0.1313

Keim, T., \& Weitzel, T. (2005). An Integrated Approach to Online Partnership Building. In Proceedings of the 38th Annual Hawaii International Conference on System Sciences. IEEE. https://doi.org/10.1109/HICSS.2005.92 
Keyzerman, Y. (2003). Trust in virtual teams. In IEEE International Professional Communication Conference, 2003. IPCC 2003. Proceedings. (p. 10 pp.). IEEE. https://doi.org/10.1109/IPCC.2003.1245520

Kirkman, B. L., \& Mathieu, J. E. (2005). The Dimensions and Antecedents of Team Virtuality. Journal of Management, 31(5), 700-718. https://doi.org/10.1177/0149206305279113

Kitchenham, B. (2004). Procedures for performing systematic reviews (technical report). Retrieved from http://www.inf.ufsc.br/ aldo.vw/kitchenham.pdf

Korsgaard, M. A., Brower, H. H., \& Lester, S. W. (2015). It Isn't Always Mutual. Journal of Management, 41(1), 47-70. https://doi.org/10.1177/0149206314547521

Kotlarsky, J., \& Oshri, I. (2005). Social ties, knowledge sharing and successful collaboration in globally distributed system development projects. European Journal of Information Systems, 14(1), 37-48. https://doi.org/10.1057/palgrave.ejis.3000520

Kozlowski, S. W. J., Chao, G. T., Grand, J. A., Braun, M. T., \& Kuljanin, G. (2013). Advancing Multilevel Research Design. Organizational Research Methods, 16(4), 581-615. https://doi.org/10.1177/1094428113493119

Krebs, S. A., Hobman, E. V., \& Bordia, P. (2006). Virtual Teams and Group Member Dissimilarity. Small Group Research, 37(6), 721-741. https://doi.org/10.1177/1046496406294886

Krumm, S., Terwiel, K., \& Hertel, G. (2013). Challenges in Norm Formation and Adherence. Journal of Personnel Psychology, 12(1), 33-44. https://doi.org/10.1027/1866-5888/a000077

Ku, H.-Y., Tseng, H. W., \& Akarasriworn, C. (2013). Collaboration factors, teamwork satisfaction, and student attitudes toward online collaborative learning. Computers in Human Behavior, 29(3), 922-929. https://doi.org/10.1016/j.chb.2012.12.019

Kuo, F., \& Yu, C. (2009). An Exploratory Study of Trust Dynamics in Work-Oriented Virtual Teams. Journal of Computer-Mediated Communication, 14(4), 823-854. https://doi.org/10.1111/j.1083-6101.2009.01472.x

Lane, M. S., \& Lum, W. H. (2011). Examining client perceptions of partnership quality and the relationships between its dimensions in an IT outsourcing relationship. Australasian Journal of Information Systems, 17(1). https://doi.org/10.3127/ajis.v17i1.525

Lee-Kelley, L., Crossman, A., \& Cannings, A. (2004). A social interaction approach to managing the "invisibles" of virtual teams. Industrial Management $\mathcal{E}$ Data Systems, 104(8), 650-657. https://doi.org/10.1108/02635570410561636

Lee, C.-C., \& Chang, J.-W. (2013). Does Trust Promote More Teamwork? Modeling Online Game Players' Teamwork Using Team Experience as a Moderator. Cyberpsychology, Behavior, and Social Networking, 16(11), 813-819. https://doi.org/10.1089/cyber.2012.0461

Lewicki, R. J., \& Bunker, B. B. (1995). Trust in relationships: A model of development and decline. In B. B. B. J. Z. Rubin (Ed.), Conflict, cooperation, and justice: Essays inspired by the work of Morton Deutsch (pp. 133-173). San Francisco, CA, US: Jossey-Bass.

Lewicki, R. J., \& Bunker, B. B. (1996). Developing and Maintaining Trust in Work Relationships. In R. M. Kramer \& T. R. Tyler (Eds.), Trust in Organizations: Frontiers of 
Theory and Research (pp. 114-139). 2455 Teller Road, Thousand Oaks California 91320 United States: SAGE Publications, Inc. https://doi.org/10.4135/9781452243610.n7

Lewicki, R. J., McAllister, D. J., \& Bies, R. J. (1998). Trust and Distrust: New Relationships and Realities. The Academy of Management Review, 23(3), 438-458.

Lewicki, R. J., Tomlinson, E. C., \& Gillespie, N. (2006). Models of Interpersonal Trust Development: Theoretical Approaches, Empirical Evidence, and Future Directions. Journal of Management, 32(6), 991-1022. https://doi.org/10.1177/0149206306294405

Li, Y., Li, H., Mädche, A., \& Rau, P.-L. P. (2012). Are you a trustworthy partner in a crosscultural virtual environment? In Proceedings of the 4th international conference on Intercultural Collaboration - ICIC '12 (pp. 87-96). New York, New York, USA: ACM Press. https://doi.org/10.1145/2160881.2160895

Liao, C. (2017). Leadership in virtual teams: A multilevel perspective. Human Resource Management Review. https://doi.org/10.1016/j.hrmr.2016.12.010

Lind, M. (2007). Collective Team Identification in Temporary Teams. In 2007 40th Annual Hawaii International Conference on System Sciences (HICSS'07) (pp. 37-37). IEEE. https://doi.org/10.1109/HICSS.2007.132

Liu, X., Magjuka, R. J., \& Lee, S. (2008). An examination of the relationship among structure, trust, and conflict management styles in virtual teams. Performance Improvement Quarterly, 21(1), 77-93. https://doi.org/10.1002/piq.20016

Lojeski, K. S., Reilly, R., \& Dominick, P. (2006). The Role of Virtual Distance in Innovation and Success. In Proceedings of the 39th Annual Hawaii International Conference on System Sciences (HICSS'06). IEEE. https://doi.org/10.1109/HICSS.2006.484

Lu, M., Watson-Manheim, M. B., Chudoba, K. M., \& Wynn, E. (2006). Virtuality and Team Performance: Understanding the Impact of Variety of Practices. Journal of Global Information Technology Management, 9(1), 4-23. https://doi.org/10.1080/1097198X.2006.10856412

Lukić, J., \& Vračar, M. (2018). Building and nurturing trust among members in virtual project teams. Strategic Management, 23(3), 10-16. https://doi.org/10.5937/StraMan1803010L

Maier, R. (2007). Knowledge Management Systems. Berlin, Heidelberg: Springer Berlin Heidelberg. https://doi.org/10.1007/978-3-540-71408-8

Majchrzak, A., Malhotra, A., \& John, R. (2005). Perceived Individual Collaboration Know-How Development Through Information Technology-Enabled Contextualization: Evidence from Distributed Teams. Information Systems Research, 16(1), 9-27. https://doi.org/10.1287/isre.1050.0044

Marks, M. A., Mathieu, J. E., \& Zaccaro, S. J. (2001). A Temporally Based Framework and Taxonomy of Team Processes. Academy of Management Review, 26(3), 356-376

Markus, M. L., \& Robey, D. (1988). Information Technology and Organizational Change: Causal Structure in Theory and Research. Management Science, 34(5), 583-598. https://doi.org/10.1287/mnsc.34.5.583 
Marlow, S. L., Lacerenza, C. N., \& Salas, E. (2017). Communication in virtual teams: a conceptual framework and research agenda. Human Resource Management Review. https://doi.org/10.1016/j.hrmr.2016.12.005

Martins, L. L., Gilson, L. L., \& Maynard, M. T. (2004). Virtual Teams: What Do We Know and Where Do We Go From Here? Journal of Management, 30(6), 805-835. https://doi.org/10.1016/j.jm.2004.05.002

Maruping, L. M., \& Agarwal, R. (2004). Managing team interpersonal processes through technology: A task-technology fit perspective. Journal of Applied Psychology, 89(6), 975990. https://doi.org/10.1037/0021-9010.89.6.975

Mathieu, J. E., Marks, M. A., \& Zaccaro, S. J. (2001). Multiteam Systems. In D. S. Ones, N. Anderson, C. Viswesvaran, \& H. K. Sinangil (Eds.), Handbook of Industrial, Work $\mathcal{E}$ Organizational Psychology - Volume 2: Organizational Psychology (pp. 289-313). Thousand Oaks, CA: SAGE Publications Ltd. http://doi.org/10.4135/9781848608368.n16

Mayer, R., Davis, J., \& Schoorman, F. (1995). An Integrative Model of Organizational Trust. The Academy of Management Review, 20(3), 709-734.

McAllister, D. J. (1995). Affect- and Cognition-Based Trust as Foundations for Interpersonal Cooperation in Organizations. Academy of Management Journal, 38(1), 24-59. https://doi.org/10.2307/256727

McGrath, J. E. (1991). Time, Interaction, and Performance (TIP). Small Group Research, 22(2), 147-174. https://doi.org/10.1177/1046496491222001

McHugh, O., Conboy, K., \& Lang, M. (2012). Agile Practices: The Impact on Trust in Software Project Teams. IEEE Software, 29(3), 71-76. https://doi.org/10.1109/MS.2011.118

McKnight, D. H., \& Chervany, N. L. (1996). The Meanings of Trust. Retrieved from http://www.misrc.umn.edu/workingpapers/fullpapers/1996/9604_040100.pdf

McKnight, D. H., \& Chervany, N. L. (2000). What is Trust? A Conceptual Analysis and an Interdisciplinary Model. In Proceedings of the 6th Americas Conference on Information Systems (pp. 827-833).

McKnight, D. H., Cummings, L. L., \& Chervany, N. L. (1998). Initial Trust Formation in New Organizational Relationships. The Academy of Management Review, 23(3), 473-490.

McNab, A. L., Basoglu, K. A., Sarker, S., \& Yu, Y. (2012). Evolution of cognitive trust in distributed software development teams: a punctuated equilibrium model. Electronic Markets, 22(1), 21-36. https://doi.org/10.1007/s12525-011-0081-z

Meyerson, D., Weick, K. E., \& Kramer, R. M. (1996). Swift Trust and Temporary Groups. In R. M. Kramer \& T. R. Tyler (Eds.), Trust in organizations: Frontiers of theory and research (pp. 166-195). Thousand Oaks, CA, US: Sage Publications, Inc. https://doi.org/10.4135/9781452243610.n9

Mirel, B., \& Johnson, N. (2006). Social Determinants of Preparing a Cyber-Infrastructure Innovation for Diffusion. Technical Communication Quarterly, 15(3), 329-353. https://doi.org/10.1207/s15427625tcq1503_4 
Mital, M., Israel, D., \& Agarwal, S. (2010). Information exchange and information disclosure in social networking web sites. The Learning Organization, 17(6), 479-490. https://doi.org/10.1108/09696471011082349

Mitchell, A., \& Zigurs, I. (2009). Trust in virtual teams. ACM SIGMIS Database, 40(3), 61-83. https://doi.org/10.1145/1592401.1592407

Mogan, S., \& Wang, W. (2007). A study into user perceptions of information sharing and trust in virtual teams. In Proceedings of the 18th conference on Hypertext and hypermedia - HT '07 (pp. 43-44). New York, New York, USA: ACM Press. https://doi.org/10.1145/1286240.1286254

Mohr, L. B. (1982). Explaining Organizational Behavior. San Francisco: Jossey-Bass.

Monalisa, M., Daim, T., Mirani, F., Dash, P., Khamis, R., \& Bhusari, V. (2008). Managing Global Design Teams. Research-Technology Management, 51(4), 48-59. https://doi.org/10.1080/08956308.2008.11657514

Morgan, L., Paucar-Caceres, A., \& Wright, G. (2014). Leading Effective Global Virtual Teams: The Consequences of Methods of Communication. Systemic Practice and Action Research, 27(6), 607-624. https://doi.org/10.1007/s11213-014-9315-2

Morris, D. Z. (2017). New french law bars work email after hours. Retrieved January 16, 2018, from http://fortune.com/2017/01/01/french-right-to-disconnect-law/

Muganda, N., \& Pillay, K. (2013). Forms of power, politics and leadership in asynchronous virtual project environment. International Journal of Managing Projects in Business, 6(3), 457-484. https://doi.org/10.1108/IJMPB-11-2011-0075

Mukherjee, D., Hanlon, S. C., Kedia, B. L., \& Srivastava, P. (2012). Organizational identification among global virtual team members. Cross Cultural Management: An International Journal, 19(4), 526-545. https://doi.org/10.1108/13527601211270002

Murthy, D., Rodriguez, A., \& Lewis, J. (2013). Examining the Formation of Swift Trust within a Scientific Global Virtual Team. In 2013 46th Hawaii International Conference on System Sciences (pp. 353-362). IEEE. https://doi.org/10.1109/HICSS.2013.211

Nandhakumar, J., \& Baskerville, R. (2006). Durability of online teamworking: patterns of trust. $\begin{array}{lllll}\text { Information Technology } \mathcal{E} \text { People, } & \text { 19(4), }\end{array}$ https://doi.org/10.1108/09593840610718045

Narayanan, V. K., Zane, L. J., \& Kemmerer, B. (2011). The Cognitive Perspective in Strategy: An Integrative Review. Journal of Management, 37(1), 305-351. https://doi.org/10.1177/0149206310383986

Newell, S., David, G., \& Chand, D. (2007a). An analysis of trust among globally distributed work teams in an organizational setting. Knowledge and Process Management, 14(3), 158168. https://doi.org/10.1002/kpm.284

Newell, S., David, G., \& Chand, D. (2007b). Exploring Trust among Globally Distributed Work Teams. In 2007 40th Annual Hawaii International Conference on System Sciences (HICSS'07) (p. 246c-246c). IEEE. https://doi.org/10.1109/HICSS.2007.221

Nunamaker, J. F., Briggs, R. O., Mittleman, D. D., Vogel, D. R., \& Pierre, B. A. (1996). Lessons from a Dozen Years of Group Support Systems Research: A Discussion of Lab and Field 
Findings. Journal of Management Information Systems, 13(3), 163-207. https://doi.org/10.1080/07421222.1996.11518138

Nyström, C. A., \& Asproth, V. (2013). Virtual Teams - Support for Technical Communication? Journal of Organisational Transformation $\mathcal{E}$ Social Change, 10(1), 64-80. https://doi.org/10.1179/1477963312Z.0000000006

O'Leary, \& Cummings. (2007). The Spatial, Temporal, and Configurational Characteristics of Geographic Dispersion in Teams. MIS Quarterly, 31(3), 433. https://doi.org/10.2307/25148802

Okoli, C., \& Schabram, K. (2010). A Guide to Conducting a Systematic Literature Review of Information Systems Research. Working Papers on Information Systems, 10(26), 1-51. https://doi.org/10.2139/ssrn.1954824

Oleson, K. E., Billings, D. R., Kocsis, V., Chen, J. Y. C., \& Hancock, P. A. (2011). Antecedents of trust in human-robot collaborations. In 2011 IEEE International Multi-Disciplinary Conference on Cognitive Methods in Situation Awareness and Decision Support (CogSIMA) (pp. 175-178). IEEE. https://doi.org/10.1109/COGSIMA.2011.5753439

Olson, J., Appunn, F., Walters, K., Grinnell, L., \& McAllister, C. (2012). The Value Of Webcams For Virtual Teams. International Journal of Management $\mathcal{E}$ Information Systems, 16(2), 161171. https://doi.org/10.19030/ijmis.v16i2.6915

Olson, J., \& Olson, L. (2012). Virtual team trust: Task, communication and sequence. Team Performance Management: An International Journal, 18(5/6), 256-276. https://doi.org/10.1108/13527591211251131

Ortiz de Guinea, A., \& Paré, G. (2017). What literature review type should I conduct? In The Routledge Companion to Management Information Systems (pp. 73-82). London: Routledge. https://doi.org/10.4324/9781315619361

Pangil, F., \& Moi Chan, J. (2014). The mediating effect of knowledge sharing on the relationship between trust and virtual team effectiveness. Journal of Knowledge Management, 18(1), 92 106. https://doi/10.1108/JKM-09-2013-0341

Panteli, N., \& Duncan, E. (2004). Trust and temporary virtual teams: alternative explanations and dramaturgical relationships. Information Technology \& People, 17(4), 423-441. https://doi.org/10.1108/09593840410570276

Panteli, N., \& Tucker, R. (2009). Power and trust in global virtual teams. Communications of the ACM, 52(12), 113-115. https://doi.org/10.1145/1610252.1610282

Paré, G., Trudel, M.-C., Jaana, M., \& Kitsiou, S. (2015). Synthesizing information systems knowledge: A typology of literature reviews. Information \& Management, 52(2), 183-199. https://doi.org/10.1016/j.im.2014.08.008

Paul, S., \& He, F. (2012). Time Pressure, Cultural Diversity, Psychological Factors, and Information Sharing in Short Duration Virtual Teams. In 2012 45th Hawaii International Conference on System Sciences (pp. 149-158). IEEE. https://doi.org/10.1109/HICSS.2012.593

Pearlson, K. E., Saunders, C. S., \& Galletta, D. F. (2016). Managing and Using Information Systems: A Strategic Approach (6th ed.). New York, NY: Wiley. 
Peñarroja, V., Orengo, V., Zornoza, A., \& Hernández, A. (2013). The effects of virtuality level on task-related collaborative behaviors: The mediating role of team trust. Computers in Human Behavior, 29(3), 967-974. https://doi.org/10.1016/j.chb.2012.12.020

Peters, L. M., \& Karren, R. J. (2009). An Examination of the Roles of Trust and Functional Diversity on Virtual Team Performance Ratings. Group \& Organization Management, 34(4), 479-504. https://doi.org/10.1177/1059601107312170

Peters, L. M., \& Manz, C. C. (2007). Identifying antecedents of virtual team collaboration. Team Performance Management, 13(3/4),

$117-129$. https://doi.org/http://dx.doi.org/10.1108/13527590710759865

Piccoli, G., Ives, B., \& Piccoli, B. G. (2003). Trust and the unintended effects of behavior control in virtual teams. MIS Quarterly, 27(3), 365-396.

Pinjani, P., \& Palvia, P. (2013). Trust and knowledge sharing in diverse global virtual teams. Information \& Management, 50(4), 144-153. https://doi.org/10.1016/j.im.2012.10.002

Plotnick, L., Hiltz, S. R., \& Ocker, R. J. (2011). Trust over Time and Distance in Global Partially Distributed Teams. In 2011 44th Hawaii International Conference on System Sciences (pp. 110). IEEE. https://doi.org/10.1109/HICSS.2011.460

Polzer, J. T., Crisp, C. B., Jarvenpaa, S. L., \& Kim, J. W. (2006). Extending the Faultline Model to Geographically Dispersed Teams: How Colocated Subgroups can Impair Group Functioning. Academy of Management Journal, 49(4), 679-692. https://doi.org/10.5465/AMJ.2006.22083024

Poole, M. S. (1981). Decision development in small groups I: A comparison of two models. Communication Monographs, 48(1), 1-24. https://doi.org/10.1080/03637758109376044

Poole, M. S. (1983). Decision development in small groups, III: A multiple sequence model of group decision development 1. Communication Monographs, 50(4), 321-341. https://doi.org/10.1080/03637758309390173

Powell, A., Galvin, J., \& Piccoli, G. (2006). Antecedents to team member commitment from near and far. Information Technology \& People, 19(4), 299-322. https://doi.org/10.1108/09593840610718018

Powell, A., Piccoli, G., \& Ives, B. (2004). Virtual teams. ACM SIGMIS Database, 35(1), 6-36. https://doi.org/10.1145/968464.968467

Privman, R., Hiltz, S. R., \& Wang, Y. (2013). In-Group (Us) versus Out-Group (Them) Dynamics and Effectiveness in Partially Distributed Teams. IEEE Transactions on Professional Communication, 56(1), 33-49. https://doi.org/10.1109/TPC.2012.2237253

Purvanova, R. K. (2013). The Role of Feeling Known for Team Member Outcomes in Project Teams. Small Group Research, 44(3), 298-331. https://doi.org/10.1177/1046496413480244

Purvanova, R. K. (2014). Face-to-face versus virtual teams: What have we really learned? The Psychologist-Manager Journal, 17(1), 2-29. https://doi.org/10.1037/mgr0000009

Radcliffe, L. L., \& Schniederjans, M. J. (2003). Trust evaluation: an AHP and multi-objective programming approach. Management Decision, 41(6), 587-595. https://doi.org/10.1108/00251740310484867 
Ragu-Nathan, T. S., Tarafdar, M., Ragu-Nathan, B. S., \& Tu, Q. (2008). The Consequences of Technostress for End Users in Organizations: Conceptual Development and Empirical Validation. Information Systems Research, 19(4), 417-433. https://doi.org/10.1287/isre.1070.0165

Rämö, H. (2004). Moments of trust: temporal and spatial factors of trust in organizations. $\begin{array}{llll}\text { Journal of Managerial } & \text { Psychology, }\end{array}$ https://doi.org/10.1108/02683940410568248

Remidez Jr., H., Stam, A., \& Laffey, J. M. (2007). Web-Based Template-Driven Communication Support Systems. International Journal of E-Collaboration, 3(1), 65-73. https://doi.org/10.4018/jec.2007010104

Riemer, K., \& Scifleet, P. (2012). Enterprise Social Networking in Knowledge-Intensive Work Practices: A Case Study in a Professional Service Firm. In Proceedings of the 23rd Australasian Conference on Information Systems (pp. 1-12). Geelong, Australia.

Robert, L. P., Denis, A. R., \& Hung, Y.-T. C. (2009). Individual Swift Trust and KnowledgeBased Trust in Face-to-Face and Virtual Team Members. Journal of Management Information Systems, 26(2), 241-279. https://doi.org/10.2753/MIS0742-1222260210

Rousseau, D. M., Sitkin, S. B., Burt, R. S., \& Camerer, C. (1998). Not So Different After All: A Cross-Discipline View Of Trust. Academy of Management Review, 23(3), 393-404. https://doi.org/10.5465/AMR.1998.926617

Rusman, E., van Bruggen, J., Sloep, P., \& Koper, R. (2010). Fostering trust in virtual project teams: Towards a design framework grounded in a TrustWorthiness ANtecedents (TWAN) schema. International Journal of Human-Computer Studies, 68(11), 834-850. https://doi.org/10.1016/j.ijhcs.2010.07.003

Rusman, E., van Bruggen, J., Sloep, P., Valcke, M., \& Koper, R. (2013). The Mind's Eye on Personal Profiles: A Cognitive Perspective on Profile Elements that Inform Initial Trustworthiness Assessments and Social Awareness in Virtual Project Teams. Computer Supported Cooperative Work (CSCW), 22(2-3), 159-179. https://doi.org/10.1007/s10606-0129171-5

Rutkowski, A.-F., \& Saunders, C. S. (2018). Emotional and Cognitive Overload: The Dark Side of Information Technology. London, UK: Routledge.

RW3 CultureWizard. (2016). Trends in Global Virtual Teams: Virtual Teams Survey Report 2016. Retrieved January 18, 2018, from http://cdn.culturewizard.com/PDF/Trends_in_VT_Report_4-17-2016.pdf

Salas, E., Burke, C. S., \& Cannon-Bowers, J. A. (2000). Teamwork: Emerging principles. International Journal of Management Reviews, 2(4), 339-356. https://doi.org/10.1111/14682370.00046

Saldaña, J. (2015). The Coding Manual for Qualitative Researchers (3rd ed.). London: SAGE Publications Ltd.

Sarker, S., Ahuja, M., Sarker, S., \& Kirkeby, S. (2011). The Role of Communication and Trust in Global Virtual Teams: A Social Network Perspective. Journal of Management Information Systems, 28(1), 273-310. https://doi.org/10.2753/MIS0742-1222280109 
Sarker, S., \& Sahay, S. (2003). Understanding Virtual Team Development: An Interpretive Study. Journal of the Association for Information Systems, 4(1), 1-38.

Sarker, S., Valacich, J. S., \& Sarker, S. (2003). Virtual Team Trust. Information Resources Management Journal, 16(2), 35-55. https://doi.org/10.4018/irmj.2003040103

Saunders, C. S., \& Ahuja, M. K. (2006). Are All Distributed Teams the Same? Differentiating Between Temporary and Ongoing Distributed Teams. Small Group Research, 37(6), 662700. https://doi.org/10.1177/1046496406294323

Scheidel, T. M., \& Crowell, L. (1964). Idea development in small discussion groups. Quarterly Journal of Speech, 50(2), 140-145. https://doi.org/10.1080/00335636409382654

Schiller, S. Z., Mennecke, B. E., Nah, F. F.-H., \& Luse, A. (2014). Institutional boundaries and trust of virtual teams in collaborative design: An experimental study in a virtual world environment. Computers in Human Behavior, 35(0), 565-577. https://doi.org/10.1016/j.chb.2014.02.051

Scott, M. E. (2013). "Communicate Through the Roof": A Case Study Analysis of the Communicative Rules and Resources of an Effective Global Virtual Team. Communication Quarterly, 61(3), 301-318. https://doi.org/10.1080/01463373.2013.776987

Short, J. (2009). The Art of Writing a Review Article. Journal of Management, 35(6), 1312-1317. https://doi.org/10.1177/0149206309337489

Skjerve, A. B., \& Rindahl, G. (2010). Promoting trust between members of distributed teams. In 2010 IEEE International Conference on Systems, Man and Cybernetics (pp. 1650-1658). IEEE. https://doi.org/10.1109/ICSMC.2010.5642403

Staples, D. S. (1997). An Investigation of Information Technology-Enabled Remote Management and Remote Work Issues. Australasian Journal of Information Systems, 4(2). https://doi.org/10.3127/ajis.v4i2.362

Staples, D. S., \& Webster, J. (2008). Exploring the effects of trust, task interdependence and virtualness on knowledge sharing in teams. Information Systems Journal, 18(6), 617-640. https://doi.org/10.1111/j.1365-2575.2007.00244.x

Tarmizi, H., Payne, M., Noteboom, C., Zhang, C., Steinhauser, L., Vreede, G.-J. de, \& Zigurs, I. (2007). Collaboration engineering in distributed environments. E-Service Journal, 6(1), 7697.

Thomas, D., \& Bostrom, R. (2008). Building Trust and Cooperation through Technology Adaptation in Virtual Teams: Empirical Field Evidence. Information Systems Management, 25(1), 45-56. https://doi.org/10.1080/10580530701777149

Tingley, K. (2017). Learning to Love our Robot Co-workers. Retrieved January 16, 2018, from https://www.nytimes.com/2017/02/23/magazine/learning-to-love-our-robot-coworkers.html

Tomlinson, E. C., Dineen, B. R., \& Lewicki, R. J. (2009). Trust congruence among integrative negotiators as a predictor of joint-behavioral outcomes. International Journal of Conflict Management, 20(2), 173-187. https://doi.org/10.1108/10444060910949621

Townsend, A. M., DeMarie, S. M., \& Hendrickson, A. R. (1998). Virtual Teams: Technology and the Workplace of the Future. The Academy of Management Executive, 12(3), 17-29. 
Tsai, Y.-H., Ma, H.-C., Lin, C.-P., Chiu, C.-K., \& Chen, S.-C. (2014). Group social capital in virtual teaming contexts: A moderating role of positive affective tone in knowledge sharing. Technological Forecasting and Social Change, 86, 13-20. https://doi.org/10.1016/j.techfore.2013.08.015

Tseng, H., \& Ku, H. (2011). The relationships between trust, performance, satisfaction, and development progressions among virtual teams. The Quarterly Review of Distance Education, 12(2), 81-94.

Van de Ven, A. H., \& Poole, M. S. (2005). Alternative Approaches for Studying Organizational Change. Organization Studies, 26(9), 1377-1404. https://doi.org/10.1177/0170840605056907

van der Land, S. F., Schouten, A. P., Feldberg, F., Huysman, M., \& van den Hooff, B. (2015). Does Avatar Appearance Matter? How Team Visual Similarity and Member-Avatar Similarity Influence Virtual Team Performance. Human Communication Research, 41(1), 128-153. https://doi.org/10.1111/hcre.12044

van Knippenberg, D., Dahlander, L., Haas, M. R., \& George, G. (2015). Information, Attention, and Decision Making. Academy of Management Journal, 58(3), 649-657. https://doi.org/10.5465/amj.2015.4003

Verburg, R. M., Bosch-Sijtsema, P., \& Vartiainen, M. (2013). Getting it done: Critical success factors for project managers in virtual work settings. International Journal of Project Management, 31(1), 68-79. https://doi.org/10.1016/j.ijproman.2012.04.005

vom Brocke, J., Simons, A., Riemer, K., Niehaves, B., Plattfaut, R., \& Cleven, A. (2015). Standing on the shoulders of giants: Challenges and recommendations of literature search in information systems research. Communications of the Association for Information Systems, 37(1), 205-224.

Walther, J. B., \& Bunz, U. (2005). The Rules of Virtual Groups: Trust, Liking, and Performance in Computer-Mediated Communication. Journal of Communication, 55(4), 828-846. https://doi.org/10.1111/j.1460-2466.2005.tb03025.x

Watkins, M. D. (2013). Making Virtual Teams Work: Ten Basic Principles. Harvard Business Review. Retrieved from https://hbr.org/2013/06/making-virtual-teams-work-ten

Watson-Manheim, M. B., Chudoba, K. M., \& Crowston, K. (2002). Discontinuities and continuities: a new way to understand virtual work. Information Technology \& People, 15(3), 191-209. https://doi.org/10.1108/09593840210444746

Weakley, A., \& Edmonds, E. (2004). Shared Visualizations in Support of Distributed Creative Communities. Australasian Journal of Information Systems, 11(2). https://doi.org/10.3127/ajis.v11i2.130

Webster, J., \& Watson, R. T. (2002). Analyzing the past to prepare for the future: Writing a literature review. MIS Quarterly, 26(2), 13-23.

Weimann, P., Pollock, M., Scott, E., \& Brown, I. (2013). Enhancing Team Performance Through Tool Use: How Critical Technology-Related Issues Influence the Performance of Virtual Project Teams. IEEE Transactions on Professional Communication, 56(4), 332-353. https://doi.org/10.1109/TPC.2013.2287571 
Wildman, J. L., Thayer, A. L., Pavlas, D., Salas, E., Stewart, J. E., \& Howse, W. R. (2012). Team Knowledge Research: Emerging Trends and Critical Needs. Human Factors: The Journal of the Human Factors and Ergonomics Society, 54(1), 84-111. https://doi.org/10.1177/0018720811425365

Wilson, J., Crisp, C. B., \& Mortensen, M. (2013). Extending Construal-Level Theory to Distributed Groups: Understanding the Effects of Virtuality. Organization Science, 24(2), 629-644. https://doi.org/10.1287/orsc.1120.0750

Wu, K., Zhao, Y., Vassileva, J., Sun, X., \& Fan, Z. (2014). How does awareness of task conflict motivate wiki-based collaborative learning? A design science approach. In Proceedings of the 18th Pacific Asia Conference on Information Systems.

Yusof, S. A. M., \& Zakaria, N. (2012). Exploring the State of Discipline on the Formation of Swift Trust within Global Virtual Teams. In 2012 45th Hawaii International Conference on System Sciences (pp. 475-482). IEEE. https://doi.org/10.1109/HICSS.2012.272

Zander, L., Zettinig, P., \& Mäkelä, K. (2013). Leading global virtual teams to success. Organizational Dynamics, 42(3), 228-237. https://doi.org/10.1016/j.orgdyn.2013.06.008

Zaugg, H., \& Davies, R. S. (2013). Communication skills to develop trusting relationships on global virtual engineering capstone teams. European Journal of Engineering Education, 38(2), 228-233. https://doi.org/10.1080/03043797.2013.766678

Zigurs, I., \& Buckland, B. K. (1998). A Theory of Task/Technology Fit and Group Support Systems Effectiveness. MIS Quarterly, 22(3), 313-334. https://doi.org/10.2307/249668

Zucker, L. G. (1986). Production of Trust: Institutional Sources of Economic Structure, 18401920. Research in Organizational Behavior, 8, 53-111.

\section{Appendices}

The following appendices can be accessed via http://dx.doi.org/10.3127/ajis.v23i0.1757

Appendix A. Description of Articles Included in Review

Appendix B. Conceptualizations of Trust

Appendix C. Assessment of Virtuality in Empirical Research

Appendix D. Summary of Findings about Antecedents and Consequences of Trust

Copyright: (C) 2019 Hacker, Johnson, Saunders \& Thayer. This is an open-access article distributed under the terms of the Creative Commons Attribution-NonCommercial 3.0 Australia License, which permits non-commercial use, distribution, and reproduction in any medium, provided the original author and AJIS are credited. 
Australasian Journal of Information Systems

2019, Vol 23, Research Article
Hacker, Johnson, Saunders \& Thayer

Trust in Virtual Teams

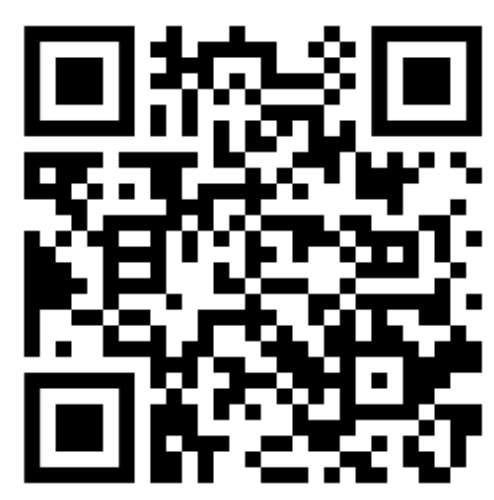

